\title{
SOBRE LAS CONTRADICCIONES CULTURALES DEL LIBERALISMO Y SUS MALESTARES
}

\author{
José Joaquín Brunner \\ Universidad Diego Portales
}

\begin{abstract}
Resumen: Este trabajo aborda la cultura liberal y las contradicciones que hoy la asedian. Por una parte, resulta evidente que la cultura liberal constituye un laberinto semántico. ¿Hay algo en ese laberinto que explique el debatido lugar que hoy tiene el liberalismo a lo ancho del mundo? Ésa es la primera pregunta que guía este ensayo. La segunda tiene que ver con que, no obstante su presencia relativamente hegemónica en Occidente, durante las últimas décadas el liberalismo y el mundo que lo acompaña —Estado, democracia, capitalismo y modernidad - generan malestares y protestas de todo orden, inconformidades que arriesgan un futuro poco promisorio. La segunda pregunta es, entonces: ¿de dónde provienen esos embates? ¿Cuál es su naturaleza? ¿En qué consiste su racionalidad?

Palabras Clave: liberalismo, cultura liberal, capitalismo, democracia, Estado, modernidad.
\end{abstract}

José Johquín Brunner. PhD en sociología por la Universidad de Leiden, Países Bajos. Profesor titular de la Universidad Diego Portales. Miembro de número de la Academia de Ciencias Sociales, Políticas y Morales del Instituto de Chile. Email: josejoaquin.brunner@cpce.com. 


\section{THE CULTURAL CONTRADICTIONS OF LIBERALISM AND ITS DISCONTENTS}

ABSTRACT: This study deals with liberal culture and the contradictions now besetting it. For one thing, liberal culture is evidently a semantic maze. Is there anything in that maze that can explain liberalism's currently contested place around the world? That is the first question guiding this essay. The second concerns the fact that, notwithstanding its relatively hegemonic position in the West, liberalism and all that accompanies it (the State, democracy, capitalism and modernity) have generated discontents and protests of all kinds over recent decades, dissatisfactions that may foreshadow an unpromising future. Where are these onslaughts coming from? What is their nature? In what does their rationality consist?

KeYwords: liberalism, liberal culture, capitalism, democracy, the State, modernity.

\section{INTRODUCCIÓN}

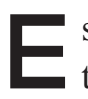

ste trabajo enfoca al liberalismo desde el punto de vista de la cultura. Es, en otras palabras, sobre la cultura liberal. Junto al Estado, a la democracia y al capitalismo, el liberalismo es hijo de la modernidad y de su compleja cultura. Como es obvio, el liberalismo heredó esta complejidad. La cultura liberal es un concepto amplio, algo difuso, en el que caben distintas ideas, las que, incluso, entran en tensión recíproca, forman laberintos y generan contradicciones.

La cultura liberal, por tanto, constituye un laberinto semántico. Y es una cultura que, no obstante su carácter relativamente hegemónico en Occidente durante las últimas décadas, hoy está bajo presión, provoca malestares y anuncia futuros turbulentos.

¿Hay en el carácter laberíntico de las palabras y de la cultura liberal una razón que explique, al menos en parte, el lugar tan debatido que ésta tiene hoy en nuestras sociedades?

Este ensayo intenta una respuesta a esa pregunta por la vía de ordenar el laberinto en dos niveles conectados entre sí: el de las palabras y el de la cultura. Estos niveles corresponden a la primera y segunda parte de este artículo. En la tercera se avanza una conclusión. El argumento se despliega como sigue. 
La primera parte (1) trata del laberinto de las palabras asociadas al liberalismo. Es un intento de elucidación conceptual, y se subdivide en tres secciones. En la primera (1.1), y para orientarse en el laberinto, el concepto de cultura liberal es analizado a la luz de la distinción núcleo/ periferia. El objetivo es discernir, hasta donde es posible, entre las nociones que marcan la diferencia específica del concepto, y las otras que lo orbitan como género próximo. En relación con esta textura abierta de la cultura liberal, la segunda sección (1.2) caracteriza las distintas variantes que del liberalismo y su cultura se han desarrollado en el tiempo; tantas, que incluso habría un liberalismo iliberal. En la última sección (1.3), la vastedad semántica del concepto es ordenada en ciertas redes de significado cuyo objetivo es, sintetizando el trabajo desarrollado hasta este punto, dar el paso a la segunda parte del artículo. El carácter multívoco de la cultura liberal, entonces, se transforma en anticipo de una cultura contradictoria.

La segunda parte (2) se ocupa de esta cultura, de su fisonomía también laberíntica, de sus contradicciones internas y malestares. Se subdivide en cinco secciones. La primera (2.1) muestra las múltiples afinidades electivas entre conceptos que pueden observarse en la literatura sobre la cultura liberal. Junto al concepto de liberalismo, los de modernidad, democracia, Estado, autonomía, capitalismo se vinculan con naturalidad a la hora de urdir dicho entramado cultural. La segunda sección (2.2) toma uno de esos conceptos, uno que encarna parte de las contradicciones de la laberíntica cultura liberal: el Estado. Desde uno idealmente mínimo en los orígenes, a uno que se expande en función de una creciente oferta de servicios públicos. Luego, en la tercera sección (2.3), se examina el concepto de democracia. Aquí las tensiones discurren entre su carácter representativo y directo, entre la deliberación política y su "judicialización”, y entre desplazamientos al interior de la ciudadanía que está a la base de esta democracia liberal, marcada por el hecho de un pluralismo sin precedentes. La cuarta sección (2.4) se concentra en el capitalismo. Sus contradicciones ya fueron diagnosticadas por Weber: la potencia irracional de la racionalidad instrumental y la creciente mercantilización de las relaciones humanas y sus formas de vida, entre otras. La quinta sección (2.5) se concentra en el concepto de cultura moderna en la que se ha desarrollado la cultura liberal. Sus contradicciones son, también, varias: la autonomía individual, de un 
lado, y la a veces asfixiante racionalización de la sociedad, junto con el desencanto de una "jaula de hierro" autoimpuesta en nombre de la emancipación.

En la conclusión (3), este conjunto de contradicciones son sintetizadas y dan pie para afirmar que la cultura liberal está hoy bajo una enorme presión histórica, con una capacidad algo agotada de pensarse a sí misma, sin la fuerza suficiente como para orientarse al interior del laberinto. Ni qué decir para encontrar la salida.

\section{EN EL LABERINTO DE LAS PALABRAS}

Thomas Nagel está en lo cierto cuando señala que "un hecho significativo de nuestra época es que la mayor parte de la discusión politica en el mundo occidental se da entre distintas ramas de la tradición [liberal]" (Nagel 2003, 62). Esta victoria ideológica es reconocida tanto por los autodefinidos como liberales como por sus críticos. A comienzos del nuevo milenio, Perry Anderson protestaba que "por primera vez desde la Reforma no existen grandes oposiciones —esto es, perspectivas sistemáticamente rivales - al interior del pensamiento de Occidente; y difícilmente tampoco a escala mundial" (Anderson 2000, 13). En tono de queja más que de celebración, Raymond Geuss concuerda: "No conocemos otro acercamiento a la sociedad humana que sea tan teóricamente rico y comprehensivo como el liberalismo, al mismo tiempo tan ampliamente aceptado a lo ancho de la población de las sociedades occidentales" (Geuss 2002, 320). La mayoría de los habitantes de Occidente son ahora conscriptos del liberalismo: el alcance de la tradición se ha expandido hasta abarcar a casi todas las posiciones políticas aceptadas como legitimas.

Duncan Bell, "What is Liberalism?” $(2014,689)$

El liberalismo ha fallado; no porque se haya quedado corto, sino porque ha sido fiel a sí mismo. Ha fallado porque ha tenido éxito. A medida que el liberalismo ha completado más propiamente su proyecto, a medida que su lógica interna se ha hecho más evidente y sus contradicciones más manifiestas, ha generado patologías que a la vez son deformaciones de su búsqueda y logros de su ideología. Una filosofía política que se lanzó para alcanzar mayor equidad, defender 
la convivencia del pluralismo de diferentes culturas y creencias, proteger la dignidad humana y, por supuesto, expandir la libertad, en la práctica genera una titánica desigualdad, empuja la uniformidad y la homogeneidad, produce degradación material y espiritual, y degrada la misma libertad.

Patrick Deneen, Why Liberalism Failed $(2018,3)$

La cultura liberal y sus contradicciones es un campo semánticamente cargado. Dicho con un vocablo de moda, existen malestares "en" y "de" la cultura liberal, cuando se cumplen dos décadas desde que en Chile se inició su estudio sistemático con la publicación de un informe sobre las "paradojas de la modernización" (PNUD 1998). ${ }^{1}$

Por lo que toca a la noción de "cultura liberal", si bien ella gira en torno al concepto-eje de "liberal" y sus múltiples ramificaciones al interior del liberalismo, a la vez se halla conectada — desde sus orígenes- a un contexto más amplio de significados, al cual concurren otros términos, igualmente complejos, como democracia, capitalismo, mercado y modernidad, con los cuales el liberalismo comparte relaciones de afinidad electiva. ${ }^{2}$ De la cultura liberal puede decirse, todavía con mayor razón que del concepto del "liberalismo", que se asemeja a un cuarto de estar que contiene varias piezas de mobiliario:

Si entramos a uno y encontramos libertad, racionalidad e individualismo en su centro, con igualdad si bien visible nada más que decorando la pared, estamos frente a un ejemplar de liberalismo. Si en cambio, al abrir la puerta, orden, autoridad y tradición atraen nuestra mirada, mientras la igualdad ha sido puesta debajo de la cama o, en el mejor de los casos, se muestra un débil

${ }^{1}$ Un respaldo académico-conceptual del informe se encuentra en Lechner (1988; 2003). Un excelente resumen de la tesis en Lechner (1998). Una visión crítica en Brunner (1998).

${ }^{2}$ Sobre este concepto, ver Löwy (2004). Este autor ofrece allí la siguiente definición del concepto weberiano de afinidades electivas: "Proceso a través del cual dos formas culturales - religiosas, intelectuales, políticas o económicas- que poseen ciertas analogías, parentescos íntimos o afinidades de significado entran en una relación de mutua atracción e influencia, se seleccionan mutuamente, convergen activamente y se refuerzan la una con la otra" (Löwy 2004, 100). Salvo indicación en contrario, todas las traducciones de los textos citados fueron realizadas para este trabajo. 
espécimen de ella únicamente cuando hay visitas, estamos frente a una versión de la ideología conservadora. Núcleo, zona adyacente y periferia organizan el cuarto y permiten así su categorización. (Freeden 1996, 86-7) ${ }^{3}$

Podría anticiparse pues, prolongando esta metáfora, que en el cuarto donde está la "cultura liberal" el mobiliario es más numeroso, más intrincadas las relaciones núcleo, zona contigua y periferia y que ésta, a su vez, conecta con el entorno a través de un verdadero laberinto donde habitan $-\mathrm{y}$ se comunican entre sí- los otros macro-conceptos recién señalados. A dicho laberinto mayor dedicaremos la segunda parte de este ensayo.

\subsection{Ideología y niveles de conceptos}

Por el momento nos situaremos dentro del cuarto del liberalismo. Si nos atenemos a los reportes que proporcionan las visitas que vienen a este cuarto, cada una descubre allí diferentes piezas de mobiliario. Por ejemplo, Freeden sostiene que la morfología conceptual del liberalismo es la de una ideología compuesta por siete conceptos políticos que interactúan en su núcleo: libertad, racionalidad, individualidad, progreso, sociabilidad, interés general y poder limitado y responsable (en el sentido de accountable) (Freeden 2015,15). Por su parte, Fawcett, en un estudio reciente, sostiene que - de manera incontrovertible - el núcleo del liberalismo incluye los derechos de las personas, la tolerancia, un gobierno constitucional, el imperio de la ley y la libertad. Pero, agrega,

${ }^{3}$ El análisis del autor es más sutil; contiene dos ejes de los cuales aquí empleamos uno solo. Según señala el propio Freeden en otra parte, "las ideologías poseen una estructura elaborada, que puede analizarse en torno a dos ejes. Primero, hay una distinción en tres anillos entre conceptos (anillo intermedio), sus micro-componentes, y sus concatenaciones macro-conceptuales. (...) El arreglo entre componentes genera diversas concepciones de cada concepto, mientras que los clusters de conceptos organizan la específica anatomía de una ideología. Al interior de estos clusters relativamente flexibles se encuentra el segundo eje; la distinción entre conceptos-núcleo, adyacentes y periféricos. La relación entre conceptos es aquí decisiva; su posición relativa no se halla tallada en piedra y fluctuará - aunque a velocidades variables - a lo largo del tiempo y del espacio" (Freeden 2013, 124). 
no hay un entendimiento intuitivo de estas ideas, ni sobre cuál comanda o cómo se interrelacionan en una lista característicamente liberal (Fawcett 2014, pos. $405-421){ }^{4}$

Bell, a su turno, argumenta que el tipo de definiciones que aquí revisamos, a las cuales denomina "estipulativas", buscarían determinar las condiciones necesarias (aunque raramente suficientes) para considerar al liberalismo como un ejemplar legítimo de una tradición de pensamiento. Típicamente, el procedimiento utilizado sería construir el significado del término a partir de interpretaciones del sentido y la interpenetración entre conceptos nucleares (core concepts), como libertad, autoridad, autonomía e igualdad. Tales interpretaciones, entonces, demarcarían los límites legítimos del liberalismo, insistiendo en que sólo aquellas definiciones ajustadas a los sentidos estipulados podrán contar como tales (Bell 2014, 686).

Otro procedimiento utilizado para determinar el significado del liberalismo como ideología asocia los conceptos nucleares, adyacentes y, en menor medida, periféricos, a ciertas filiaciones de pensamiento dentro de redes de autores. Freeden habla a este propósito de los "grandes" o las "luminarias" liberales; otros, menos coloridamente, de pensadores fundamentales o autores claves o tradiciones principales. Cada intérprete posee su lista favorita. Por ejemplo, el británico Freeden (2015, cap. 5) menciona entre sus "grandes", durante su recorrido por los siglos XIX y XX, a cuatro ingleses - J.S. Mill, T. H. Green, L.T. Hobhouse y J. A. Hobson- y a una inglesa, M. Wollstonecraft. En Francia nombra a B. Constant; en Alemania, a Wilhelm von Humboldt y a Max Weber, por su versión, dice, elitista y nacionalista del liberalismo; y en Italia, a Benedetto Croce, L. Einaudi y Carlo Rosselli, este último un liberal de izquierda, como lo fueron también los ingleses Hobhouse y Hobson,

${ }^{4}$ Además, tan importante como el listado de estos conceptos, es observar el hecho de que todos ellos fueron asumidos por diversos grupos en Europa, especialmente desde el siglo XVII, llegando a reflejar una conciencia general de la modernidad en el siglo XIX. Según señala Delanty, "eran ideas contra-factuales, habitualmente articuladas por grupos sociales opositores y movimientos contrarios al statu quo. Sin embargo, como atestigua la historia de las ideas liberales, existían interpretaciones muy diferentes de sus implicaciones para el diseño de la sociedad" (Delanty 2015, 431). 
igual que el norteamericano John Dewey, un liberal progresista que tenía una visión pragmática y reformista del liberalismo. ${ }^{5}$

En cambio, Gerald F. Gaus, filósofo político contemporáneo, distingue entre dos grandes escuelas liberales. Por un lado, describe un liberalismo basado en la Ilustración, heredero de Locke, Kant y Mill, entre cuyos representantes contemporáneos menciona a Galston, Raz y Rasmussen. Esta visión del liberalismo cree posible, mediante el uso de la razón, arribar a verdades universales sobre cuestiones de moralidad y perfección humana. Por otra parte, existiría un liberalismo postilustrado, no en cuanto pudiese rehusar la convicción de que la libertad es un principio político público respaldado por la razón, sino en cuanto busca explicar cómo ese tipo de principios puede existir en un mundo donde el ejercicio de la razón frecuentemente lleva a divergencias y desacuerdos. Esta versión del liberalismo parte, más bien, cuestionando que en la esfera política puedan invocarse siquiera verdades morales. Según sostiene Rawls, a quien Gaus cita en esta última perspectiva del pensamiento liberal, los desacuerdos sobre qué es un bien y cómo uno debería conducir su vida son un "resultado normal del ejercicio de la razón humana dentro del marco de instituciones libres propio de un régimen constitucional democrático" (Rawls 1996, xviii). Al liberalismo postilustrado le cabría pues la tarea, dice Gaus, "de mostrar que nuestra razón no siempre [cursiva del autor] nos lleva a discrepar. Si bien el desacuerdo racional es generalizado, se halla contenido por una razón pública que justifica un orden político basado en la libertad" (Gaus 2003, 19). Los liberales postilustrados que estudia Gaus buscan en filósofos como Hobbes, los románticos y Rousseau argumentos para aquella tarea. Entre los autores más conocidos analiza, además de Rawls, a Isaiah Berlin, John Gray y Jürgen Habermas.

Esta variedad de referencias en los laberintos definicionales del liberalismo, su ideología y cultura se multiplica como ecos en unos enrarecidos espacios semánticos. Por ejemplo, Geuss ordena dichas referen-

${ }^{5}$ Un enunciado representativo de Dewey y su personal formulación liberal se encuentra en el siguiente pasaje: "Las dos cosas esenciales para comprender en detalle el liberalismo social son: primero, un estudio realista de las condiciones existentes dentro del movimiento, y, segundo, ideas rectoras, en forma de políticas que intenten ir en interés de un incremento de la individualidad y la libertad" (Dewey 1935, 228). 
cias a partir de las perspectivas provistas por diferentes tradiciones del pensamiento liberal. Así, señala que mientras para Humboldt, Constant, Mill y Tocqueville los asuntos focales eran tolerancia, libertad e individualismo, en cambio la idea de justicia se encontraba completamente ausente (Constant) o era, en el mejor de los casos, un asunto marginal (J.S. Mill), diríamos situado en la periferia, o bien, por último, un objeto de desconfianza porque llevaba a pensar que presuponía una visión unitaria, centralizada, de la sociedad que constituía un peligro para el individualismo (Humboldt) (Geuss 2002, 324). Geuss plantea que los componentes principales del liberalismo clásico serían, primero, la tolerancia como virtud cardinal; segundo, la especial importancia normativa otorgada a la libertad de asociación (relaciones voluntarias entre personas), en particular el libre asentimiento como única fuente de la autoridad política; tercero, el compromiso con el individualismo: una sociedad es buena sólo en la medida del bienestar de sus miembros individuales, y, cuarto, un tipo particular de ansiedad liberal, el miedo al poder ilimitado, concentrado o arbitrario. De allí que "limitar el poder ha sido siempre un objetivo de la política liberal”, remata (Geuss 2002, 323).

\subsection{Diversidad en todas las direcciones}

De manera tal que, a medida que se avanza en la exploración del significado de la cultura liberal, necesariamente irá complejizándose la metáfora original del cuarto de Freeden, sobreponiéndose otras perspectivas referidas a tradiciones de pensamiento, autores claves, escuelas nacionales o, incluso, metáforas alternativas para acceder a la arquitectura conceptual del liberalismo. Por ejemplo, según Walzer, los teóricos del liberalismo proclaman y practican un "arte de la separación" o de la distinción. Trazan líneas, demarcan dominios y crean mapas sociopolíticos que mantienen vigencia hasta ahora. La más famosa línea de demarcación, dice él, es aquel "muro" levantado entre la iglesia y el Estado; pero hay muchas otras, agrega. ${ }^{6}$ El liberalismo sería pues un mundo de muros, cada uno dando lugar a una nueva libertad (Walzer 1984). De ahí también la idea, esgrimida por los críticos del liberalismo, de que estos muros simbólicos habrían aumentado en exceso, al punto de sepa-

\footnotetext{
${ }^{6}$ Este tema es explorado, por ejemplo, en Rico (2010).
} 
rar a los individuos entre sí; cada hombre y mujer un reino separado por sus posesiones, libre para intercambiar por encima de las fronteras de su encierro egoísta. Pero no nos adelantemos; esta crítica (Chmielewski 2007, por ejemplo) forma parte ya de las contradicciones y malestares de la cultura liberal.

Las calificaciones de, y las contraposiciones entre, liberalismos - pues es en plural que debemos referirnos a ellos de aquí en adelante- son múltiples. Antiguo y moderno (Strauss 1968); de identidades o de ciudadanía, sobre los cuales Marc Lilla (2017) ha escrito un libro recientemente; universalistas e igualitarios frente a otros particularistas y de élite, a los que se refiere Beetham (1989) a propósito del lugar de Max Weber en la tradición liberal, asunto al que volveremos más adelante; las variantes moderna, clásica, social y libertaria del liberalismo que distingue Alan Ryan (2012) y las variedades conservadora, nacionalista, imperialista, progresista e, incluso, más recientemente, de un liberalismo iliberal, en versiones más virulentas o atemperadas.

¿Liberalismo iliberal, dice usted? Efectivamente. Según una literatura reciente (y creciente), este tipo de liberalismo distorsionado se produce mediante el empleo de elementos seleccionados del discurso y la ideología liberales para defender posiciones que, en última instancia, son profundamente iliberales, especialmente en cuanto se oponen a algunos conceptos nucleares del liberalismo, como libertad, autonomía y progreso en su concepción occidental. Esta formulación iliberal se ha incorporado también al vocabulario de la política contingente. Un caso bien conocido es el del primer ministro húngaro Viktor Orbán, quien en una presentación del año 2014 declara: la "nación húngara no es una mera suma de individuos, sino una comunidad que necesita organizarse, ser fortalecida y desarrollarse y, en este sentido, el nuevo Estado que estamos construyendo es un Estado iliberal, un Estado no liberal". ${ }^{7}$ En ge-

${ }^{7}$ Presentación en Băile Tuşnad del año 2014, citada en Harper (2018). Es interesante lo que Harper agrega en otra parte del mismo artículo: "La antigua democracia ateniense, siendo radical en su práctica e ideología, era claramente no liberal. No existían derechos fundamentales ni doctrinas acerca de la dignidad inherente del ser humano. Los privilegios de la participación política se restringían a los ciudadanos libres de sexo masculino. Había esclavos en abundancia. Había tendencias xenófobas que harían sonrojarse al más ardiente miembro del Amanecer Dorado [partido ultranacionalista griego]. Había una religión oficial del Estado. En síntesis, ésta era la democracia antes del liberalismo. El hecho de que esta de- 
neral, estas tendencias iliberales se manifestarían ante todo en el campo de las libertades socioculturales - especialmente frente a políticas de inmigración, asuntos de igualdad de género y derechos de la comunidad LGBT, libertad de expresión y tratamiento de otras creencias religiosas en el marco de lo que un autor denomina "secularismo cristiano" (Hibbard 2015) - y tendrían por objetivo limitar la tolerancia (liberal) solamente a aquellos que toleran a otros cuyos valores y prácticas culturales no comparten (Moffitt 2017, 115-117). En consecuencia, se trataría de un liberalismo schmittiano, en tanto busca identificar y proteger, mediante el uso del poder coercitivo del Estado, los valores nucleares del liberalismo frente a grupos iliberales peligrosos (Triadafilopoulos 2011, 863).

Las justificaciones invocadas para el liberalismo iliberal son de interés aquí pues conectan con varios tópicos que serán tratados en la segunda parte. En primer lugar, reflejan la amplitud que adquiere el empleo del vocablo liberalismo en las actuales condiciones del mundo occidental, aun partiendo de una línea base de conceptos claves mínimos que formarían el núcleo de esta ideología. En segundo lugar, muestran el uso táctico — o la derecha manipulación — a que pueden someterse dichos conceptos nucleares, de modo de aprovechar lo que un grupo de coautores denomina el Zeitgeist cívico, caracterizado hoy (todavía) por una corriente general en favor de la tolerancia, la diversidad y los derechos de las personas (Halikiopoulou et al. 2013, 109). Por último, en tercer lugar, y en este mismo contexto de época, estas formas distorsionadas de ideología liberal conectan —en su entorno semántico — con fenómenos como el de las llamadas "democracias iliberales" (Zakaria 2003), democracias defectivas y autoritarismos electorales (Bogaards 2009) o competitivos (Levitsky y Way 2002), capitalismos de partido

mocracia fuera tan abiertamente no liberal demuestra que la síntesis moderna de liberalismo y democracia no es inevitable ni necesaria" (Harper 2018). Un ejemplo adicional, esta vez referido al Asia, se menciona a propósito de los riesgos que traen consigo los procesos de de-consolidación de la democracia. Allí, leemos, "la noción de democracia iliberal (frecuentemente ofrecida como parte del argumento sobre 'valores asiáticos') hace tiempo se ha propuesto como una alternativa de los checks and balances del constitucionalismo liberal. Esta versión de la democracia significa típicamente menos restricciones institucionales para líderes populistas o de orientación autoritaria, y una más débil accountability y control por parte de los medios de comunicación" (Davis 2017, 147). 
único (Kurlantzick 2016; Csillag y Szelényi 2015), modernidades múltiples y modernidad iliberal (Snyder 2017, 2016). ${ }^{8}$

El número siempre en aumento de categorías, clasificaciones y distinciones respecto del liberalismo, al cual Dunn (1991) se refiere con cierta frustración, no agota sin embargo las posibilidades de ordenamiento del campo discursivo del liberalismo y su cultura acumulada a lo largo de los últimos tres siglos. Él mismo glosa ideas y disposiciones que serían parte del núcleo de esta tradición, "incluyendo racionalismo político, hostilidad hacia la autocracia, disgusto cultural ante el conservantismo y la tradición, tolerancia e individualismo" (Dunn 1991, 33). Así, la literatura continúa generando nuevos conceptos nucleares, adyacentes y periféricos, y nuevas combinaciones de significado con conceptos vinculados del entorno, hasta encontrarse con la vertiente del neoliberalismo, seguramente la más sobresaliente - y prolífica, a su turno, en cuanto a la generación de nuevas posibilidades de comprensión e interpretación del fenómeno liberal- durante el periodo de tránsito del siglo XX al XXI (Boas y Gans-Morse 2009; Schmidt 2016). Esta vertiente, además, parece haber convocado buena parte de las críticas que se han dirigido al liberalismo en el último tiempo. Por esto es posible pensar que la presión bajo la cual se encuentra la cultura liberal sea en parte responsabilidad de ella misma.

Otra fuente productiva de debates sobre el significado del liberalismo durante los últimos años ha sido la contraposición y competencia entre las tesis opuestas de un liberalismo en su hora triunfante - the universalization of Western liberal democracy as the final form of human government (Fukuyama 1989, 4) - y un liberalismo en su hora de crisis y retirada - the retreat of western liberalism (Luce 2017)-, ambas con seguidores y detractores, según ponen de manifiesto los epígrafes que encabezan esta parte del artículo. La tesis triunfalista, según la cual "el liberalismo se habría convertido en una metacategoría del discurso político de Occidente" (Bell 2014, 683), se asocia a Fukuyama ante todo y, aunque probablemente tiene hoy más detractores que partidarios, todavía resuena en frases como ésta: "No hay alternativas democráticas para aquello denominado habitualmente el modelo occi-

${ }^{8}$ Además, puede verse la interesante ponencia de David-Fox (2006) y el artículo ya citado anteriormente de Moffitt (2017) sobre la interacción entre el vocabulario del liberalismo y los vocabularios del populismo de derechas e izquierdas. 
dental de democracia; sólo modelos no democráticos" (Alexander 2005, 159). Una idea similar defiende Richard Bernstein, quien dice tener la corazonada de que el pensamiento político y social occidental podría haber experimentado ya la última revolución conceptual requerida. La sugerencia de J. S. Mill de que los gobiernos deben dedicarse a optimizar el balance entre no entrometerse en la vida privada de las personas y prevenir el sufrimiento, le parece a él muy próxima a la última palabra que sobre estas materias se puede y necesita decir. En tanto, "descubrir quiénes sufren puede dejarse en manos de la prensa libre, universidades independientes y una opinión pública esclarecida" (Bernstein 2003, 130).

La tesis del decaimiento democrático liberal, en cambio, parece estar al alza, según muestra la reciente aparición de una serie de libros que en sus títulos hacen referencia a la ruina del demo, a la democracia occidental bajo amenaza, la pérdida de su magia, la tragedia, el retiro, el vaciamiento y el entrampamiento de la confianza (Hobson 2016). ${ }^{9}$ Tendremos oportunidad de retornar a estos asuntos en la segunda parte.

A las diferentes formulaciones e interpretaciones de los liberalismos - que preparan nuestro acercamiento a las tensiones, contradicciones y malestares en la cultura liberal contemporánea - deberíamos agregar todavía las diversas perspectivas que proporcionan las diferentes disciplinas y los enfoques académicos, como la filosofía política, el derecho, la historia de las ideas e ideologías, la economía política, la antropología, los estudios de cultura comparada, la ciencia política, la sociología cultural y otros acercamientos académicos que sin duda contribuirían a esta exploración (Freeden 2007; Freeden et al. 2013; Maynard y Mildenberger 2016), pero requerirían el trabajo de un equipo interdisciplinario y la elaboración de un extenso informe, muy distinto del presente texto.

De cualquier forma, suficiente complejidad tenemos ya entre manos con la exploración llevada a cabo hasta este punto; un breve recorrido — podríamos decir puramente topográfico — por los cuartos de la ideología liberal, con su núcleo central, zonas adyacentes, periferias y entornos. Hemos podido apreciar que los conceptos nucleares - trátese

${ }^{9}$ Los libros comentados por Hobson son: Brown (2015), Coggan (2013), Dunn (2013), Johnston (2015), Kurlantzick (2013), Mair (2013) y Runciman (2013). 
de aquéllos enumerados por Freeden o bien por otros autores-, a pesar de su relativa convergencia, igual crean un amplio espacio de dudas e interpretaciones, pues son cambiantes, admiten diversas combinaciones y elucidaciones, carecen de una jerarquía preestablecida y se conectan de distintas maneras con las diferentes tradiciones del pensamiento liberal. Además, evolucionan en el tiempo, varían sus zonas adyacentes y periféricas, y sus conexiones con el entorno se hallan en continuo movimiento, dando lugar a diferentes ensamblajes por su articulación con otros macroconceptos, como democracia, capitalismo y modernidad, con los cuales inevitablemente entran en relación al poseer, como dijimos, afinidades electivas entre sí.

\subsection{Enfoques, métodos y justificaciones}

El propio ejercicio emprendido por Freeden (2015) para esclarecer y precisar el sentido de los conceptos claves de su liberal core semeja el esfuerzo de Sísifo. Como él mismo reconoce, incluso el concepto eje, fundante, del liberalismo, el de libertad, no por ser el primero y hallarse al centro de la línea base de la ideología y los discursos liberales, puede darse por entendido según su valor aparente. Más bien, "afirmar que el concepto de libertad es indispensable para el liberalismo es sólo el comienzo de una larga historia” (Freeden 2015, 58). Habría que preguntarse, dice él, si las personas se hallan libres de cualquier constreñimiento y, de no ser así, qué las constriñe, quién y cómo, si es la ley o son otras personas, o quizá la pobreza, la falta de recursos o la ignorancia. $\mathrm{O}$ bien, si se hallan discriminadas o excluidas de determinados bienes esenciales o carecen de las capacidades que son la base de la libertad y de la posibilidad de elegir.

Estamos pues frente a un concepto contestado, ${ }^{10}$ el cual siempre posee más de un significado plausible y se halla sujeto a - e incluso florece en medio de - disputas. Las ideologías tendrían por función, entre cosas, fijar el sentido de estos conceptos contestados; ${ }^{11}$ extraerlos de la disputa y otorgarles un significado ampliamente aceptado. Mas

10 Sobre conceptos contestados, ver Gallie (1956), Garver (1990), Abbey (2005), Collier et al. (2006), Dryzek (2016).

${ }^{11}$ Sobre la relación entre ideologías y el uso del lenguaje, ver Freeden (2017; 2018). 
tampoco esta operación resulta fácil, según comenta Freeden. Pues los diversos liberalismos tienden a darle a la libertad diferentes sentidos; por ejemplo, uno más cercano a la no intervención del Estado, la libertad negativa que protege la autonomía del individuo, o bien uno más próximo al pleno desarrollo de las personas, y que a tal efecto subraya la equidad social y el acceso igualitario a un conjunto de bienes y servicios garantizados por el Estado.

Y así la historia sigue sin detenerse y vuelve a repetirse con cada uno los demás conceptos esenciales que forman parte del núcleo: racionalidad, que puede ser entendida de acuerdo a fines o valores o, en el extremo opuesto, como un asunto de uso eficiente de medios en el desempeño de funciones; individualidad, que puede referirse a la dignidad sustantiva de las personas y su igualdad formal en la esfera de la ciudadanía o a su estatus en la sociedad civil y su capacidad efectiva de autorrealización; progreso, que representa una herencia de la Ilustración, según la cual la humanidad se hallaría en dirección a un continuo mejoramiento y superación, ${ }^{12}$ todo lo cual es contestado por otras filosofías e incluso desahuciado como un relato ficticio por el discurso de la posmodernidad; sociabilidad, entendida como una condición de mutua interdependencia y simpatía entre los seres humanos en los planos económico, social, ético, emocional o físico y, por ende, una negación del carácter solitario o monádico de los individuos ${ }^{13}$ interés general, concepto que incluiría, en la visión liberal, al conjunto de todos los individuos sin enfatizar clases, razas, género o etnicidad como puntos de ruptura, principio que naturalmente entra en conflicto con un liberalismo de las identidades y los derechos de la diversidad; ${ }^{14} \mathrm{y}$, por

${ }^{12}$ Esta idea se expresa a la manera de un lema por el joven bachiller en el Fausto de Goethe: "Con la luz ante mí y atrás la sombra" (Goethe 2005, 201).

${ }^{13}$ Este elemento queda bien expresado en un pasaje de Hegel, donde sostiene: "En la sociedad civil, cada individuo es su propio fin, y todo el resto no significa nada para él. Pero no puede lograr su propio fin en toda su plenitud si no es en relación con otros; estos otros son por lo tanto medios para el desarrollo de la persona particular. Pero, a través de esta relación con los otros, el fin particular se hace universal, y se satisface a sí mismo simultáneamente satisfaciendo el bienestar de los otros" (Hegel 1991, 227-8).

${ }^{14}$ A este propósito, Žižek formula la siguiente crítica: "Finalmente, existen todas las paradojas autorreferidas centradas en el punto muerto de la tolerancia a la intolerancia. Liberales multiculturales predican la tolerancia entre culturas a la vez que dejan en claro que la verdadera tolerancia es posible sólo en la individua- 
último, poder, entendido empero como limitado y responsable (accountable), idea que se halla en el origen de la mayoría de los liberalismos, acompañado de la preocupación constitucional por separar los poderes y crear mecanismos de balance y control recíproco entre ellos (Freeden 2015, 58-63).

De este último aspecto, central dentro de la tradición liberal —el de la limitación de la razón de Estado y el Estado policial del absolutismo- da cuenta Foucault (2016a) en una de sus clases del curso de 1978 en el Colegio de Francia, echando mano de una explicación de economía política más que política o ideológica respecto de la limitación endógena que los nacientes mercados racionales - como suele llamarlos Weber- imponen al poder central del Estado con el advenimiento del capitalismo en el siglo XVIII, y no como producto, dice él, de restricciones externas impuestas al poder del Príncipe en nombre de derechos (anteriores, naturales) de las personas o por voluntad divina. Escuchemos lo que plantea su argumento:

El juego del liberalismo: dejar que la gente haga y las cosas pasen, que las cosas transcurran -laisser faire, passer et aller, dejar hacer, pasar y transcurrir- significa esencial y fundamentalmente hacer de tal suerte que la realidad se desarrolle y marche, siga su curso de acuerdo con las leyes, los principios y los mecanismos que le son propios. Así, pues, el problema de la libertad (...) me parece que podemos considerarlo, aprehenderlo

lista cultura occidental y, por lo tanto, legitiman incluso intervenciones militares como un recurso extremo para pelear contra la intolerancia de otros" (Žižek 2008, 62). Como contraparte aparece esta otra visión, que proclama la virtud liberal de la diversidad y el pluralismo como elemento esencial de la cultura liberal: "Las culturas sociales insertas dentro de una democracia liberal moderna son inevitablemente pluralistas, conteniendo tanto a cristianos como musulmanes, judíos y ateos; a heterosexuales como a gays; a profesionales urbanos como a campesinos; a conservadores como a socialistas. Esta diversidad es el resultado inevitable de las libertades y derechos garantizados a los ciudadanos liberales - incluyendo la libertad de conciencia, de asociación, de expresión, de disidencia política y el derecho a la privacidad-, especialmente cuando se da en una población de gran diversidad étnica. Esta diversidad, sin embargo, se encuentra equilibrada y contenida por una cohesión lingüística e institucional, cohesión que no ha emergido por sí misma, sino que es resultado de deliberadas políticas de Estado" (Kymlicka 1997, 24). Para una visión radicalmente crítica del liberalismo histórico, sus promesas y realidades, véase Losurdo (2011). 
de diferentes maneras. Se puede decir, desde luego $-\mathrm{y}$ creo que no sería falso, no puede serlo- que esta ideología de la libertad, esta reivindicación de la libertad fue sin duda una de las condiciones del desarrollo de las formas modernas o, si lo prefieren, capitalistas de la economía. Es innegable. (Foucault 2016a, 70) ${ }^{15}$

En suma, identificar y poder aprehender algo así como una esencia, un núcleo conceptual elemental del liberalismo, parece una tarea interminable respecto del propio núcleo y de los variables conceptos que pueblan la zona adyacente, la periferia y, más allá, el entorno que como un laberinto de ideas se extiende en todos los sentidos. Quien arriesga entrar en este juego se expone a quedar atrapado para siempre dentro de la idea del liberalismo, con sus elementos conceptuales resonando indefinidamente como un eco que se transmite desde el centro o línea de base del núcleo hacia los espacios vecinos y luego la periferia, para terminar confundiéndose más allá con las voces que emanan de los conceptos del entorno que - como veremos a continuación - integran nuestra noción de cultura liberal, tales como democracia liberal, mercados "libres", capitalismo y modernidad.

Una manera de estabilizar, por así decir, el movimiento de estas redes de significados ha sido propuesta por Bell (2014). Consiste en una estrategia para uso, ante todo, de las discusiones académicas sobre los liberalismos en el mundo. Él propone distinguir tres respuestas o aproximaciones a la pregunta sobre qué es el liberalismo.

${ }^{15}$ Dice un comentarista: "En mi perspectiva, lo que es interesante de la línea foucaultiana de investigación es esto: (...) Foucault dice que el liberalismo consiste en una transferencia de racionalidad aplicada hacia el dominio de la economía. (...) Foucault pensó que el liberalismo puede ser visto como un arte de gobierno, que primero cristalizó en tres creencias básicas: a) el mercado es una técnica de 'veridicción'; b) el cálculo que envuelve la utilidad de las decisiones es una herramienta para el control del poder, y c) Europa puede ser el sujeto de un crecimiento económico ilimitado dentro de un mercado global (Cain 2016, 6). La noción de "veridicción", según explica el propio Foucault, significa establecer una verdad (del mercado) frente al gobierno; "debe revelar algo semejante a una verdad", puesto que los precios, "en cuanto se ajustan a los mecanismos naturales del mercado, van a constituir un patrón de verdad que permitirá discernir en las prácticas gubernamentales las que son correctas y las que son erróneas". En fin, concluye él, "el mercado constituye un lugar de veridicción, y con ello quiero decir un lugar de verificación y falseamiento de la práctica gubernamental" (Foucault 2016b, 49). 
La primera corresponde al método prescriptivo; especifica normas de uso correcto o buen uso, buscando determinar cuál concepción del liberalismo sería la mejor y más auténtica o verdaderamente liberal, proponiendo medios para reconocer los elementos constitutivos, como pueden ser los conceptos nucleares, metodologías interpretativas para identificarlos y la disposición normativa sostenida frente a ellos. La segunda es una respuesta comprensiva; procede reuniendo toda la variedad de discursos liberales para a partir de ahí tratar de determinar el mapa, topografía y usos discursivos, sin prescribir una concepción determinada. Y la tercera es la respuesta explicativa, la cual se ocupa de exponer la evolución de los liberalismos, sea que se los haya definido prescriptiva o comprensivamente.

Para completar este esquema, el autor propone protocolos interpretativos que designa como de tipo estipulativo, canónico y contextual. El primero, ya lo vimos anteriormente, estipula qué versiones de liberalismo pueden considerarse ejemplares legítimos de una tradición discursiva, habitualmente mediante la identificación de conceptos claves. El método canónico, en cambio, procede mediante la identificación de autores descollantes de las tradiciones de pensamiento relevantes - los grandes pensadores o luminarias de Freeden-y sus textos claves, que fijan el canon de los great books. Por último, el método contextualista, que el propio Bell favorece, consistiría en un análisis comprensivo del liberalismo que provea "un marco de referencia para captar las diversas vías de emergencia del lenguaje liberal y la manera cómo entran en conflicto entre sí, antes que tratar de destilar un conjunto ahistórico de compromisos liberales resultantes de la investigación conceptual o canónica" (Bell 2014, 689). Siguiendo esta línea argumental, propone la siguiente definición: "La tradición liberal está constituida por la suma de argumentos que han sido clasificados como liberales, y han sido reconocidos como tales por otros que también se proclaman liberales, a través del tiempo y el espacio. Llamaremos a ésta una concepción sumativa" (Bell 2014, 689-690).

A la hora de hacer un balance tras este recorrido por las galerías interiores y encrucijadas del laberinto conceptual de los liberalismos, hemos recurrido a Bell por ser el autor que da cuenta de la más amplia extensión y variedad de argumentos liberales sin tener que entrar en la interminable discusión sobre las esencias conceptuales y los ejemplares legítimos de la tradición. Este enfoque estimula el examen de dichas 
tradiciones como fenómenos histórico-evolutivos y disputados, que entretejen el trabajo de muy diversos pensadores y "empresarios ideológicos" y de políticas públicas, académicos, especialistas y de todo tipo de intérpretes, transmisores pedagógicos y divulgadores (Hall 1993; Campbell 2002; Campbell y Pedersen 2015; Gunn 2017). "Nos permite pues entender la intrincada dialéctica de la acción humana intencional y las consecuencias no deseadas que estructuran cualquier tradición política intelectualmente densa" (Bell 2014, 690).

Por lo demás, este autor no es el único que está tras el esfuerzo por definir la ideología liberal a partir del "giro lingüístico" (Freeden 2006, 2013; Norval 2013; Stråth 2013); ${ }^{16}$ esto es, concentrándose en las palabras, los argumentos y el análisis de los discursos (Schmidt 2015). Freeden, a quien venimos citando con cierta frecuencia a lo largo de esta trayectoria dentro del laberinto, postula en términos similares que el liberalismo es

aquel campo semántico en el cual pueden investigarse los entendimientos políticos de la gente que se ve a sí misma, u otros consideran, como liberales. Es una materia plástica, cambiante, hecha y rehecha por las prácticas de pensamiento de individuos y grupos. Y si bien requiere tener un patrón gruesamente identificable para nosotros poder llamarlo consistentemente con el mismo nombre, "liberalismo", presenta también innumerables variaciones que reflejan las cuestiones formuladas y las posiciones adoptadas por diversos liberales. (Freeden 2005, 20) ${ }^{17}$

En suma, como ha dicho el autor del primer epígrafe que encabeza esta parte,

liberalismo es el fantasma que recorre al pensamiento y la práctica política de Occidente. Para algunos es el espacio de la modernidad, un objeto de deseo, incluso el fin (telos) de la historia. Para

${ }^{16}$ En efecto, durante los años 1980 surge un nuevo enfoque metodológico y epistemológico para el estudio de las ideologías, bajo el nombre de "giro lingüístico". Como bien explica Stråth, "el gradual quiebre de esta perspectiva hizo posible ver ideologías como marcos interpretativos, constituidos por campos semánticos y conceptos clave. Este punto de vista invitó a hacer análisis de las luchas de poder discursivo basado en la apropiación de conceptos políticos claves y la ocupación de campos semánticos (Stråth 2013, 15).

${ }^{17}$ Véase asimismo Freeden y Stears (2013). 
otros representa una pesadilla en curso; significa o la viciosa lógica del capitalismo o un sórdido descenso al relativismo moral. Todavía para otros, quizá la mayoría, es una marca de ambivalencia; el prerrequisito ideológico para vivir una vida razonablemente confortable en Estados democráticos de bienestar, la menos mala de las opciones. (Bell 2014, 683)

\section{EN EL LABERINTO DE LA CULTURA}

...la cultura es mejor vista no tanto como un conjunto complejo de patrones concretos de conductas - costumbres, usos, tradiciones, hábitos-, como ha sido considerada ampliamente hasta ahora, sino como un conjunto de mecanismo de control - planes, recetas, reglas, instrucciones (lo que los ingenieros llaman "programas")— para gobernar la conducta.

Clifford Geertz, The Interpretation of Cultures $(1973,44)$

En esta parte interesa entender las contradicciones, malestares y descontentos de, y en, la cultura liberal. Para abordar este objetivo nos hemos detenido antes - todo el tiempo que fue necesario- en el carácter liberal de dicha cultura, carácter de suyo diferenciado y complejo según acabamos de ver. Además, se manifiesta estrechamente imbricado con un entorno en el que coexiste e interactúa con otros fenómenos históricos, como la democracia, el capitalismo y la modernidad tardía, que son parte asimismo de esa cultura liberal. No podemos, claro está, realizar recorridos igualmente extensos por los laberintos conceptuales e ideológicos donde se expresan práctica y discursivamente estos otros fenómenos históricos, todos entrelazados entre sí, contribuyendo a dar significados todavía más complicadamente sobredeterminados ${ }^{18}$ a lo que llamamos "cultura liberal".

\subsection{Afinidades electivas en la cultura liberal}

Para acceder a este nivel superior de complejidad discursiva, bastará mostrar con algunas citas — suficientemente heterogéneas para

${ }^{18}$ En el sentido que poseen múltiples determinaciones que actúan recíproca, descentrada y moviblemente. Esta noción de "sobredeterminación" nada tiene que ver, por tanto, con su uso en el vocabulario de Althusser, en vilo entre Hegel y Marx. Para una discusión escolástica del uso althusseriano, véase Ambriz Arévalo (2016). 
observar el fenómeno que aquí interesa - cómo diversas literaturas especializadas asocian con gran naturalidad ciertos conceptos, como si estuviesen secretamente atraídos por unas afinidades electivas ${ }^{19}$ dentro de la noción de cultura liberal.

Así, por ejemplo, en la entrada correspondiente a "Martin Luther and Modernity, Capitalism, and Liberalism", de la Oxford Research Encyclopedias on line se lee:

El concepto de modernidad ha emergido como una categoría filosófica, teológica y sociológica principal durante el período posterior a la Revolución Francesa. Debía servir para dar cuenta de cambios fundamentales en el entramado de la cultura occidental, incluyendo el acenso del capitalismo, el liberalismo, la democracia y la secularidad. (Zachhuber 2017)

Por su parte, en el contexto de una discusión sobre Fukuyama, se sostiene que:

Como un esquema de orden social, el liberalismo descansa sobre dos pilares: democracia en la esfera política y capitalismo de mercado en la esfera económica. (Skidmore 2005, 166)

A lo cual un bien conocido intelectual de izquierdas responde:

Únicamente para la moderna cultura occidental la autonomía y libertad individuales poseen un estatus superior que la solidaridad colectiva, vinculación, responsabilidad por otros dependientes y el deber de respetar las normas de la comunidad de la cual uno es miembro. (Žižek 2008, 662)

Por su lado, en vena sociológica, Peter Wagner afirma:

Resulta relativamente evidente asumir que la democracia es la forma política prevalente de la modernidad, puesto que la democracia significa nada más que autodeterminación colectiva, particularmente en el sentido de fijar las reglas de la vida en común. (...) Menos claro, en cambio, es si el capitalismo es necesaria-

${ }^{19}$ Ver nota 2. Para un tratamiento más extenso, ver McKinnon (2010). 
mente la forma económica de la modernidad. En tanto todos los modos modernos de autocomprensión recurren a un concepto de autonomía, algunos autores sostienen que una economía de mercado es la que mejor expresa la modernidad económica, dado que enfatiza las elecciones individuales de los agentes económicos. (Wagner 2011, 3-4)

Con todo, y como se desprende de la breve selección de párrafos citados, el término "cultura liberal" propiamente no aparece directamente mencionado, ni tampoco es de amplia circulación, a diferencia, por ejemplo, de los conceptos más restringidos de liberalismo económico y liberalismo político. ${ }^{20}$ El primero de estos conceptos, como explican Simmons, Dobbin y Garrett (2006), se refiere a políticas que reducen las restricciones sobre los comportamientos económicos, promoviendo así el intercambio; es decir, la mercantilización (marketization) de esta actividad, cuyos orígenes capitalistas modernos estudia Polanyi (2001; también Beckert 2007; Hodgson 2017). El segundo concepto, en tanto, se refiere a políticas que reducen las restricciones gubernamentales del comportamiento político, promueven el libre intercambio político y establecen derechos de participación política; o sea, la democratización, en la tradición inaugurada por Locke (Arneson 2016).

Cultura liberal, más difícil de definir en pocas palabras, puede entenderse entonces, convencionalmente, como la constelación de ideas, valores, sentimientos, ideologías, marcos de referencia y prácticas que acompañan, a la manera de una superestructura, la estructura económica y política de los mercados y la democracia, a la vez que dan sustento

${ }^{20}$ Uno de los escasos artículos que apuntan en la dirección que aquí exploramos es uno de Hearn. Dice este autor: "Las economías capitalistas y las instituciones democráticas son los pilares de la sociedad liberal. Pero deseo evitar reducir la idea de sociedad liberal a los efectos de las instituciones, sean políticas o económicas. Prefiero realizar, en cambio, un análisis más cultural. Por cultura no me refiero a las artes (sean populares o de elite), la producción intelectual o, en su sentido más amplio, la producción de símbolos y significados, ideas, valores o creencias (...). Aunque incorporo esta dimensión, mi concepción no es tan conceptual y prefiero retomar una tradición antropológica, más antigua y holística, que ve la cultura como el conjunto de formas - tanto materiales como conceptuales, cognitivas y afectivas - de organizar y encauzar la vida social, lo cual incluye las instituciones y las estructuras en sí mismas, no sólo las ideas acerca de esas instituciones y estructuras" (Hearn 2011, 203). 
al liberalismo económico y político; es decir, favorece políticas, arreglos institucionales, motivaciones y conductas que promueven la mercantilización y democratización de la sociedad. ${ }^{21}$ Las ideas liberales a su turno - según vimos en la primera parte - son una tradición de pensamiento y una ideología que gira en torno a un conjunto de ideas básicas, referidas a la autonomía individual, la emancipación humana, la sociedad abierta, el pluralismo de valores, la tolerancia, la igualdad de los ciudadanos y sus derechos políticos, civiles y sociales, o a similares listados de conceptos nucleares. En Occidente, estas ideas se expresan en creencias, filosofías, instituciones, prácticas y procedimientos, dando lugar a variadas narrativas que se entretejen a lo largo de la historia en relación con términos tales como modernidad, capitalismo, democracia, Estado de derecho y otros.

La cultura liberal puede entenderse, entonces, en torno a ese núcleo de ideas - cambiante y movible - que se organiza sobre la base de un conjunto limitado de conceptos claves, al mismo tiempo que en conexión con la estructura de economía política que la soporta, proporcionando el entorno para su desenvolvimiento: el capitalismo, los mercados, la democracia y su envoltura más amplia, o de época, que reconocemos como modernidad. ${ }^{22}$

Nuestro propósito, de cara a la cultura liberal, es explorar algunas de las tensiones, contradicciones y malestares que ella genera. Efectivamente, hay diversas dimensiones de la sociedad en que se manifiestan contradicciones "en" y "de" la cultura liberal; o sea, dentro de ella —en su núcleo ideológico, zona adyacente y periferia-, y respecto de su articulación con el entorno socioeconómico y político, las cuales son causantes de tensiones, malestares y descontentos. Interesa aquí primero identificar esas dimensiones y luego examinar — sin ninguna pretensión sistemática o de exhaustividad comprensiva - algunas manifestaciones de aquellas contradicciones y malestares tal como aparecen discutidos en la literatura.

Tales dimensiones no coinciden necesariamente con las esferas de valor ( $u$ órdenes de vida) que Max Weber desarrolla en medio de

${ }^{21}$ Sobre distintas formas de articulación o ensamblaje entre mercados y democracia, véase Reisman (2005).

${ }^{22}$ Sobre la conjunción argumentativa de las ideas liberales y la noción ilustrada de cultura puede consultarse Kahn (2012). 
sus escritos de sociología de la religión (Weber 1969), ${ }^{23}$ aunque guardan ciertas similitudes con aquéllas y con los efectos del capitalismo sobre la Lebensführung (conducción de vida) (Weber 2012, pos. 1296$1313)^{24}$ de diferentes grupos humanos bajo esta condición de vida. En particular, nos centraremos en las siguientes cuatro dimensiones de la sociedad liberal: (i) la dimensión correspondiente al encuentro de las personas con las burocracias a nivel de la calle (Lipsky 2010); es decir, at the point of delivery (en el punto del suministro) de los servicios sociales como proclamaba el Informe Beveridge ${ }^{25}$ (nombrado así por su autor $)^{26}$, servicios considerados primordiales para la vida cotidiana y su reproducción; (ii) aquélla referida a las características y dinámicas actuales de la democracia liberal y a la experiencia de la ciudadanía con el Estado como órgano político; (iii) aquélla relativa al desarrollo del capitalismo como soporte de la cultura liberal y a las dinámicas creadas por los mercados y sus efectos; y (iv) aquélla relacionada con la modernidad tardía como dimensión del espíritu de la época (Zeitgeist) en que

${ }^{23}$ Puede verse un análisis más reciente sobre este tópico en Friedland (2013).

24 Análisis contemporáneos de este término clave se encuentran en Scott (2012) y Müller (2017).

25 Sobre la recepción de este informe, se dijo: “Convirtió a su autor en un héroe público virtualmente de la noche a la mañana: influenció los debates de posguerra acerca de la reforma social, a través de toda Europa occidental y el mundo angloparlante. Su adopción por el Partido Laborista favoreció el triunfo de éste inmediatamente después de la guerra. Entre 1946 y 1951, un amplio abanico de prestaciones sociales, incluyendo el seguro social universal y el Servicio Nacional de Salud (NHS, por su sigla en inglés), fue introducido. Analistas contemporáneos de políticas públicas, como T. H. Marshall, argumentaron que estas medidas representan la culminación de los derechos de ciudadanía en Europa occidental, ya que al remover los riesgos asociados al capitalismo industrial crearon una alternativa democrática al comunismo soviético" (Whiteside 2014).

26 William Beveridge, que hoy aparece como un influyente epígono de sí mismo ejerciendo directa o indirecta influencia intelectual sobre el pensamiento socialdemócrata, en Chile por ejemplo, fue un (auto)definido liberal, aunque del tipo que suele llamarse "social" o, en la tradición británica, "nuevo" liberal. He aquí su propia definición: "Libertad significa más que protección frente al poder de los gobernantes. Significa libertad frente a la servidumbre económica del deseo, la miseria y otros males sociales; significa libertad frente a cualquier forma de poder arbitrario. Un hombre hambriento no es libre, porque hasta que reciba alimento, sus pensamientos no irán más allá de sus urgentes necesidades físicas; como hombre está reducido a la calidad de animal. Un hombre que no puede expresar la sensación de injusticia o humillación frente a su empleador, por riesgo de caer en el desempleo crónico, no es libre" (Beveridge 1945, 9). 
se desenvuelve actualmente la cultura liberal y sus conceptos nucleares, adyacentes y periféricos, especialmente en aspectos claves que interesan a la sociología cultural.

En lo que ahora sigue, se pasará revista a cuatro de estos conceptos fundamentales que, entrelazados, subyacen en la cultura liberal. Son, en el mismo orden: Estado, democracia, capitalismo y cultura moderna.

\subsection{El ogro filantrópico}

Los burócratas que atienden a público son grandes receptores de gasto estatal y representan una parte importante de la actividad pública a nivel local. Los ciudadanos experimentan directamente el gobierno a través de ellos y sus acciones, en buena medida, representan las politicas públicas provistas por el gobierno.

Michael Lipsky, Street-level Democracy. Dilemmas of the Individual in Public Services (2010, pos. 398-404)

La primera dimensión que interesa abordar dice relación con un tema general del que habla Alan Ryan (2012, 364-380). Él sostiene lo difícil que resulta saber cuál es la evaluación final de J. S. Mill sobre la condición de la sociedad moderna; "si acaso experimenta un déficit de autoridad, un exceso o, más plausiblemente, dice, de un déficit del tipo adecuado de autoridad y un exceso del tipo equivocado" (Ryan 2012, 365). Este problema acompaña al desarrollo de la autoconciencia liberal a lo largo del tiempo; considérese, por ejemplo, los casos de Mill, Weber y el propio Ryan.

En el caso de Mill, un eje de esta reflexión es la necesidad (utilitaria) de un "buen gobierno" que pueda impulsar el progreso de la nación $\mathrm{y}$, eventualmente, llevar al autogobierno del pueblo mediante una forma de democracia representativa. Dentro de esta línea argumental, contemplaba la necesidad de diferentes modalidades de progreso. Refiriéndose al gobierno imperial británico en la India a mediados del siglo XIX, por ejemplo, promueve ante todo su responsabilidad con el mejoramiento de las condiciones materiales - de vida e infraestructura- que son un prerrequisito, sostiene, para luego poder avanzar en otros planos conducentes eventualmente al autogobierno (Ryan 2012, 369-373). Y, en cuanto a la tarea de llevar adelante esa responsabilidad elemental del gobierno, Mill confiaba, ante todo, en una administración esclarecida, 
integrada por personas de mérito examinado. Una correcta administración debía ser parte de un gobierno deliberativo, con intercambio de opiniones, integrado por una capa de alta burocracia experta en materias de administración y un cuadro de empleados (hoy diríamos street level bureaucrats) (Lipsky, 2010), en condiciones de hacer funcionar la maquinaria administrativa en terreno, sea en la provisión de salud, educación, obras de infraestructura o en los servicios para la economía y la industria. El criterio de éxito de una administración debía ser la eficiencia, única medida en que hombres racionales podían convenir sobre los resultados de una operación, a pesar de las diferencias culturales (por ejemplo, entre un gentleman victoriano de clase media y un comerciante de la India bajo dominio colonial).

Mill ponía gran énfasis en la necesidad de contar con personal bien calificado tanto en la cúspide de la administración burocrática como en terreno, en contacto con la población. De hecho, fue uno de los inspiradores del servicio civil inglés establecido a mediados del siglo XIX. Consideraba que su establecimiento podía llegar a definir una era en la historia y significaría un gran avance público (Mill 1854, 207). Con la misma fuerza rechazaba el argumento de un acceso privilegiado de los hijos de la aristocracia y favorecía los exámenes para reclutar a los mejores en la carrera de los talentos. Pues, decía, la objeción de que la selección de los candidatos al servicio civil según sus talentos lo llenaría con gente de clase baja, sin el cultivo ni los sentimientos propios del estrato de los gentlemen, supone que estos últimos no podrían competir en instrucción y habilidad con los primeros, lo cual llamaría a adoptar reformas sociales todavía mayores. Y concluye: "Si con ventajas y oportunidades tan vastamente superiores, la juventud de la clase alta no tiene suficiente honor, o energía, o espíritu público para cualificarse tan bien como otros con el fin de mantener la posición deseada, entonces no son adecuados para esa posición y no deberían demorar en abandonarla para dar paso a gente mejor" (Mill 1854, 209). Incluso, Mill veía ventajas en todo esto para las universidades inglesas de su época, las que calificaba como instituciones que por siglos habían dejado de cumplir cualquier propósito nacional; servían, en cambio, para cementar una alianza entre una religión particular y una particular clase social en beneficio de un injusto privilegio. Por el contrario, si el acceso al servicio civil se abría a una competencia irrestricta por descubrir y formar a los 
más talentosos, entonces también las universidades se tornarían más meritocráticas, comenta Ryan (2012, 339-340).

Por necesidad, el gobierno y su personal civil de primera línea y del nivel de aplicación de las políticas necesitan contar con suficiente reconocimiento social, retribución salarial y recursos para hacer atractiva la profesión y eficiente la administración. ${ }^{27}$ Aquí el tema de los ingresos del Estado, en especial su capacidad de movilizar recursos por la vía de cobrar impuestos, adquiere una importancia decisiva para el liberalismo y la cultura liberal. El Estado limitado, con funciones básicas ("de policía" como se postulaba antiguamente) y una administración eficiente, se concibe para favorecer la iniciativa individual en el seno de la sociedad civil y de los mercados, debiendo el Estado ocuparse básicamente de garantizar la libertad y propiedad de las personas. ${ }^{28}$ Eso, en teoría liberal.

En la práctica, sin embargo, los gobiernos de los sistemas capitalistas — sean de la variedad coordinada por mercados o por el Estado (Hall y Soskice 2001) - , bajo diferentes regímenes políticos, formas de gobierno e ideologías cambiantes, arrancando desde un punto bajo de carga tributaria han debido aumentarla secularmente, para cubrir las mayores necesidades de la población, sostener el progreso material, corregir fallas del mercado y de las propias administraciones públicas, expandir la calidad de los servicios básicos, compensar externalidades y financiar una lista cada vez más extensa y variada de derechos sociales y protecciones colectivas. De hecho, alrededor de 1870, los países desarrollados del mundo - en Europa, Asia Pacífico y Norte América (14 países) - tenían en promedio un gasto general del gobierno de 10,8 por ciento del PIB, fluctuando en los extremos entre el 18,3 por ciento de Australia y menos del 6 por ciento en Noruega y Suecia. En 1960,

${ }^{27}$ Una visión reciente de estos asuntos, con foco especialmente en Chile, puede consultarse en Aninat y Razmilic (2018, especialmente 403-432 y 433-488).

${ }^{28}$ Como señala Octavio Paz, "los liberales creían que, gracias al desarrollo de la libre empresa, florecería la sociedad civil y, simultáneamente, la función del Estado se reduciría a la de simple supervisor de la evolución espontánea de la humanidad. Los marxistas, con mayor optimismo, pensaban que el siglo de la aparición del socialismo sería también el de la desaparición del Estado. Esperanzas y profecías evaporadas: el Estado del siglo XX se ha revelado como una fuerza más poderosa que la de los antiguos imperios y como un amo más terrible que los viejos tiranos y déspotas. Un amo sin rostro, desalmado y que obra no como un demonio, sino como máquina” (Paz 1979, 85). 
el promedio había ascendido a 23,8 por ciento del PIB, oscilando entre 34,1 por ciento en Alemania y 11,8 por ciento en Noruega. En 2007 el promedio era de 42 por ciento del PIB, encontrándose las cifras más alta y más baja en Suecia y en Australia, 52 y 34,9 por ciento, respectivamente (Tanzi 2011, 9). ${ }^{29}$ De manera que con relativa independencia de la evolución ideológica del capitalismo después de la revolución industrial, y de las preferencias más smithsianas o keynesianas de los gobiernos, en la práctica, el incremento de los niveles impositivos puede explicarse "por una demanda de un mayor gasto público proveniente de una parte de la población que había adquirido mayor poder político, y por la mayor oferta de ingreso impositivo debido a desarrollos administrativos y tecnológicos y de cambios estructurales en la economía" (Tanzi 2011, 94).

A su turno, esto ha obligado a que la aspiración liberal de un Estado mínimo y funcional para asegurar la máxima expansión de la iniciativa individual haya tenido que compatibilizarse con los requerimientos del gobierno representativo, como Mill llama a la democracia liberal, y de la modernidad con su cultura de derechos y de difusión de valores utilitarios. Precisamente en este contexto surge contemporáneamente, a veces en un clima de relativo pesimismo cultural, la pregunta por el exceso, la falta o un inadecuado equilibrio entre autoridad y libertad. Podemos retomar este tópico al hilo de la lectura de Authority: The Anxieties of "The Spirit of the Age", título de una colección de escritos de Mill para la prensa, producidos en tiempos de inestabilidad política y de su vida personal, sobre los cuales reflexiona Ryan (2012, 373-380). ${ }^{30}$ Entre sus preocupaciones mayores, hace casi dos siglos, se encuentran algunas compartidas en el presente: la cambiante naturaleza de estándares y convenciones, la relación entre masa e individualidad, la sumisión a la autoridad legítima o a la mera presión ejercida por la opinión pública. Le angustiaba no encontrar una respuesta adecuada para la pregunta

29 Para el caso de América Latina, puede consultarse Tanzi (2013). La cifra para el promedio de países de la OCDE alcanza en el año 2016 a 34,4 por ciento del PIB, con su punto más alto en Dinamarca ( 45,9 por ciento) y más bajo en México (17,2 por ciento). Chile se sitúa en la vecindad del punto inferior (20,5 por ciento). Ver "OECD, Revenue statistics" - "OECD countries: Comparative tables" - "Total tax revenue as percentage of GDP”, 2016, http://stats.oecd.org/Index.aspx?Query$\mathrm{Id}=21699$.

${ }^{30}$ El texto original se encuentra en Mill (1831). 
de cómo en tiempos turbulentos podían las personas vivir de acuerdo a un criterio racional de libertad al servicio del bien individual y, a la vez, converger hacia una noción de bien común con los demás individuos libres en una sociedad frecuentemente compleja.

A diferencia de Isaiah Berlin o, para el caso, de Max Weber, Mill no creía en un pluralismo radical ni compartía la imposibilidad de un consenso sobre bienes y valores últimos, imaginando, como hijo de Las Luces, que podía haber un camino racional hacia respuestas verdaderas también en otros ámbitos de la vida, igual como existían en la ciencia. Al mismo tiempo, temía, como Tocqueville, la "tiranía de las mayorías", con su efecto de presión sobre las conciencias individuales y el riesgo de reemplazar la autonomía personal del juicio moral por la heteronomía provocada por el temor de la diferenciación. Ausente pues una auténtica autoridad intelectual en la sociedad, que pudiera llevar a consensos racionalmente (o deliberativamente) fundados, al mismo tiempo que la sociedad quedaba expuesta al conformismo de las masas, Mill previó la paradoja de una situación en la cual hubiese al mismo tiempo un déficit y un exceso de libertad.

Un pensador liberal y sociólogo clave del siglo XX, Ralf Dahrendorf, aborda estos mismos asuntos pero en clave más dramática, si cabe: la de la construcción de un orden social y cultural en el momento en que las democracias capitalistas liberales de la modernidad tardía habían suprimido las anclas tradicionales, convertido a los sujetos en meras partes de unos contratos transitorios libremente adquiridos y puesto en cuestión todas las formas de autoridad legítima, dejando expuesta a las sociedades a la agresión, la brutalidad y las fuerzas hobbesianas. Retornaremos a esto al momento de examinar la cuarta dimensión de tensiones y contradicciones en la cultura liberal, aquélla referida a su desenvolvimiento en condiciones de modernidad tardía.

Por ahora, resumamos los conflictos centrales de la primera dimensión de estas perturbaciones que aparecen en la cultura liberal: frente al deseo de un Estado mínimo, una proliferación creciente de servicios público-estatales; por ende, una expansión máxima también de la zona de contacto entre los ciudadanos usuarios de esos servicios y la burocracia estatal que opera a nivel de la calle, que el liberalismo pretendía limitar en beneficio de la iniciativa individual y la autonomía de cada persona, y, por último, la constante interrogación de si en las sociedades moder- 
nas existe una falta, un exceso o una inadecuada calidad de la autoridad en relación con el despliegue de las libertades individuales.

Veamos ahora un segundo concepto central para la cultura liberal: la democracia.

\subsection{Las torsiones de la democracia liberal}

Lo interesante no es distinguir varias clases de gobierno representativo o intentar hacer entrar las posiciones de los actores o las características de las instituciones en casillas bien definidas (...). Es partir de las antinomias constitutivas de lo político, antinomias cuyo carácter no se revela más que en el despliegue histórico (...). Para pensar bien la democracia, es preciso, entonces, abandonar la idea de modelo en beneficio de la de experiencia. Las condiciones del vivir juntos y del autogobierno, en efecto, no están definidas a priori, fijadas por una tradición, o impuestas por una autoridad. Al contrario, el proyecto democrático constituye a lo político en un campo ampliamente abierto, por el hecho mismo de las tensiones y de las incertezas que le son subyacentes.

Pierre Rosanvallon, "L'universalisme démocratique: histoire et problems" (2007, 13-14,15).

La segunda dimensión que exploraremos brevemente se refiere a la democracia liberal y al Estado como aparato político que incluye al gobierno representativo, sobre todo en su mutua relación y con la sociedad civil, o sea, con su base capitalista. Ya Marx (2011) había observado que esta bifurcación del Estado como una esfera política de hombres iguales en derechos ciudadanos era una mera abstracción de su situación desigual en la sociedad civil burguesa. Las reformas en el plano del Estado, como proponían Mill y los liberales, no liberaban por lo mismo a los hombres de la alienación y las desigualdades en el plano material de la sociedad civil. Según Bensaid, la revolución francesa, al

disolver los órganos político-económicos de la sociedad feudal, dejó separada rígidamente la política y la economía. El Estado acaparó el espacio de lo político y lo económico quedó como un territorio en el que en apariencia no existía la política, sino sólo la búsqueda de la satisfacción de las necesidades individuales. La sociedad civil, dada la división de funciones con el Estado, quedó conformada como una instancia 'apolítica', en la que no cabía 
hablar de explotación, pues las relaciones imperantes eran naturales. (Bensaid 2011, 142)

Por el contrario, cabe también una lectura desde el potencial democrático que esta escisión contenía, al reconocer derechos naturales a las personas, los que debían servir de salvaguardia frente a los poderes arbitrarios y autoritarios del antiguo régimen, a la vez que como una afirmación de independencia individual en la esfera de la religión, el pensamiento, la expresión y la cultura. "En efecto, fue a través del Estado representativo que el individuo, como ciudadano, pudo exigir que se hicieran realidad en la práctica sus derechos, concepto-puente que vincula la enorme abstracción del Estado y de la ciudadanía a las personas concretas con y sus intereses y necesidades" (Galli 2013, 36). Se inicia así el camino que llevará de los derechos naturales, en la tradición de Locke, a los derechos políticos de la revolución francesa y a las luchas por la expansión del sufragio, luego — a mediados del siglo $\mathrm{XX}$ - a los derechos sociales proclamados por T. H. Marshall que buscan transformar a la sociedad civil capitalista en una esfera de bienestar compartido, y, últimamente, a los derechos culturales de diversos tipos de comunidades y colectivos que reivindican sus diferencias y la aceptación radical de un estatuto de igualdad en la diversidad (Ishay 2004).

Por esta vía, la democracia ha devenido también un espacio de tensiones y contradicciones para el liberalismo y la cultura liberal. Por lo pronto, la democracia no se agota en el sufragio y los mecanismos propiamente políticos de la representación. Tiene muchas otras maneras de expresarse que ahora la acompañan desde la sociedad civil. Por ejemplo, Rosanvallon (2008) da cuenta de tres nuevas formas de producción de democracia, cada una con sus específicas contribuciones, limitaciones y nuevas distorsiones. El primer grupo de mecanismos residiría en la función de supervisión, a través de la cual organizaciones de ciudadanos, o de la sociedad civil, u ONGs, monitorean y fiscalizan el comportamiento de las autoridades elegidas y designadas. El segundo grupo incluye diversas formas de movilización de resistencias en cada una de las fases del ciclo de políticas públicas, sea en su etapa de formulación y diseño, durante los procesos de decisión y adopción de aquéllas y durante su implementación y evaluación. Y a su turno, el tercer tipo daría lugar a nuevas expresiones de democracia; Rosanvallon lo caracteriza como 
una tendencia al "enjuiciamiento" de la política, cuando individuos o grupos concurren a los tribunales y judicializan aspectos de la política, en particular frente a casos de corrupción y conflictos de intereses.

Estas tres instancias representan, decíamos, nuevos desarrollos de la democracia, no exentos de tensiones, igual como ocurrió cuando la democracia liberal - a lo largo de su evolución - fue encontrándose con sucesivas formulaciones de los derechos de las personas y la sociedad. De hecho, los recientes desarrollos observados por Rosanvallon y comentados por Schmitter (2010) pueden ser leídos como una forma democrática de "contra-democracia", que surge desde la sociedad civil y de los hombres y mujeres concretos que buscan crear nuevas formas de poder y de control del poder en tiempos de "democracias desconfiadas", una vez perdida la legitimidad de las autoridades representativas y generalizado el distanciamiento de la ciudadanía respecto de la política y los mandatarios.

La supervisión, que contiene momentos de seguimiento, denuncia y evaluación, comprende todo lo relativo a las exigencias de información y transparencia que los ciudadanos plantean al Estado y sus agentes. Apoyada por - y actuando a través de - los medios de comunicación y las redes sociales, esta función propia de una democracia de base suele conectarse con la función de judicialización de la política (Villar 2000), en la cual intervienen activamente fiscales, policías y jueces, en una deriva en la que la denuncia de las debilidades y corrupciones de la democracia suele agravar su déficit de legitimación, la desconfianza reinante y abrir las puertas a corrientes iliberales que pueden introducir prácticas antidemocráticas y, a veces, directamente autoritarias (Minc 1995).

En este contexto, los media a través de la comunicación y el manejo público de escándalos políticos — poder, dinero y sexo- pueden asimismo causar estragos en la confianza institucional del sistema político y en las autoridades del gobierno y el Estado (Thompson 2000; Castells 2007), como pudo observarse primero en Italia, luego en Francia y España, y posteriormente en varios países de América Latina, Europa Central y Europa del Este.

Por su lado, la prevención aparece como el conjunto de resistencias movilizadas frente a la política de las políticas, movilizaciones que permiten manifestar las ideas y los intereses de un mayor número de 
partes interesadas por ser escuchadas y consideradas en los procesos de decisión pública (Brown 2017). El diseño y la formulación de políticas suelen ser contestados ahora por instituciones de tipo think tanks, agrupaciones de technopols e intelectuales públicos. También algunas universidades desarrollan esta función que J. S. Mill echaba de menos en su propio país hace dos siglos. Asimismo, en diversas democracias del mundo existe una mayor o más intensa movilización de protestas en las calles, frente a proyectos de ley discutidos en el parlamento o ante medidas del gobierno. Diversos actores de la sociedad civil intervienen activamente para favorecer u obstaculizar — por sí mismos o a través de acciones de lobby, abiertamente o mediante actuaciones y maniobras en los corredores del poder - asuntos que comprometen el interés público e intereses privados; disputan un lugar para sus asuntos en la agenda de los media y construyen relatos que les permitan incidir en las batallas discursivas.

Por último, como se vio, la tercera instancia a la que se refiere Rosanvallon, que hemos traducido como "judicialización” de la política, expande grandemente el poder de los tribunales de justicia, pero también de otros organismos jurisdiccionales del Estado y del Tribunal Constitucional, para resolver asuntos propiamente políticos que hasta ahora estaban entregados a decisiones mayoritarias en la esfera política, representativa, del Estado (Bello 2017).

Especialmente en la zona de contacto entre el Estado y los mercados, donde los intereses privados están en condiciones de colonizar el aparato público y a los funcionarios del Estado, se multiplican las ocasiones de tentación y de riesgo, a la par que aumentan las prácticas corruptas. Debido a una mayor vigilancia y supervisión social y a la capacidad de comunicación y reacción de la sociedad civil, junto con una más activa participación del ministerio público y los fiscales, dichos actos terminan ahora en los tribunales y sus protagonistas en prisión, como ha ocurrido en América Latina con centenares de altos funcionarios, parlamentarios, dirigentes de partidos e, incluso, ex presidentes de la república (Iazzetta y Stabili 2016).

La democracia liberal clásica ha estado transformándose así, en medio de desconfianzas y malestares - a través de experimentos empujados por la sociedad civil y de reformas adoptadas desde el propio Estado- , en un nuevo régimen de balances, en el que el poder se halla 
simultáneamente más concentrado y más disperso, en el que los actores se multiplican, la competencia puramente electoral pasa a ser complementada por numerosas formas de conflicto y ajuste, el pluralismo de valores y perspectivas se vuelve cada vez más expansivo y los límites entre el Estado, los mercados y la sociedad civil se hallan en constante redefinición (Swyngedouw 2005).

En suma, la democracia liberal aparece, por una parte, superada por unos Estados de bienestar que, en virtud de ingresos tributarios cada vez mayores, extienden sus funciones sociales en todas las direcciones y, por otra parte, se ve forzada a disminuir la brecha que separa a la sociedad civil, con sus desigualdades reales, de la esfera política ciudadana con sus igualdades puramente formales. Se transforma de arriba hacia abajo expandiendo el alcance de sus tecnoburocracias y, de abajo hacia arriba, por la irrupción de la vigilancia, la prevención y la judicialización, que imponen un mayor control de las autoridades elegidas y designadas y a sus planteles de expertos. No es ya una mera expresión de la sociedad capitalista burguesa, pero, al mismo tiempo, continúa desarrollándose conflictiva y contradictoriamente en el seno del capitalismo tardío moderno.

Por una parte, la democracia liberal aparece entonces como un sistema de alienación, propulsado por las desigualdades apenas veladas de una ciudadanía no sólo formal, sino ficticia, que suele replegarse y se abstiene de participar. Por otra parte, amenaza a los individuos mediante el conformismo y la presión social, entrometiéndose en su vida privada y llevando su vigilancia hasta los patios interiores de la intimidad, a través de nuevos dispositivos tecnológicos y de las redes sociales que tornan transparentes incluso las minucias de la vida cotidiana (Fuchs 2014; Fuchs y Trottier 2015).

En fin, con Galli $(2013,58,60)$ podemos decir que "los problemas de la democracia se deben hoy en día a factores internos más que a enemigos externos, a la entropía más que a la colisión", mientras "se registra un progresivo desalineamiento entre Estado, mercado, nación y partidos". A los cuales cabe agregar, la ciudadanía.

De ser concebida desde las izquierdas marxistas del siglo XIX como un artificio de la política liberal y del Estado representativo, la ciudadanía pasó a ser durante buena parte del siglo XX un sujeto de derechos sociales que tenía como contraparte a un Estado de bienestar ex- 
pansivo sobre una base de ingresos tributarios continuamente ampliada. Hoy, esta ciudadanía aparecería básicamente en dos nuevos registros.

En primer lugar, toma una forma comercializada, en el tipo al que refiere Crouch $(2017,78-103)$, quien habla de una commercialization of citizenship y la concibe como el resultado de la mercantilización y privatización de una amplia gama de servicios sociales que hasta ayer habían formado parte de una ciudadanía política de derechos sociales, en la tradición del liberalismo social y del Estado de bienestar. El término comercialización, tal como es empleado aquí, refiere a todas aquellas prácticas que se supone podrán mejorar la calidad de los servicios públicos mediante el reemplazo de su actual modalidad de organización y ethos público por modalidades típicas de la activad comercial de las empresas organizadas bajo un ethos privado. Sería pues la reversión del principio de derechos sociales de T. H. Marshall, a los cuales se accede sólo en virtud de la condición de ciudadano. Es decir, aquellos servicios públicos dejarían de ser parte de aquellas cosas que, de acuerdo a varios pensadores liberales, el dinero o el mercado no debieran proveer (Roth 2007; Sandel 2012). Según el alegato de Crouch, estaríamos en presencia - en la actual fase, que él caracteriza como de post-democracia (social) - de la disolución del paquete de ciudadanía inspirado por T. H. Marshall e implementado, bajo una variedad de formas, por el Estado de bienestar. Los riesgos que esto traería consigo serían aumentar las desigualdades dentro de las sociedades nacionales, aumentar el flujo comercial — a nivel global — de servicios esenciales para la población y reducir aún más el alcance de lo público en favor de los intereses privados y de una commodification de las relaciones humanas.

$\mathrm{Y}$ en segundo lugar, la ciudadanía aparecería bajo la forma de grupos y colectivos de identidad étnica, de género, de nación o cultura, en un juego de diversidades que va más allá de los individuos y agrega un frente adicional de tensiones a la cultura liberal. La desaparición o difuminación del demos da lugar al surgimiento continuo, conflictivo, de variados nuevos sujetos sociales (no políticos) que son cada vez más especializados en sus demandas y posiciones (Innerarity 2017): movimientos étnicos, LTBG, territorial-locales, animalistas, veganos, de indignados, anárquicos, de defensa medioambiental, feministas, estudiantiles, de tercera y cuarta edad, de padres y apoderados y comunidades escolares, neo-luditas contrarios al lucro y al valor de cambio, 
sectas religiosas y proféticas, colectivos de consumidores, círculos de personas con dificultades de vida y salud, comunidades de existencias alternativas, de promoción u oposición de causas morales, de exigencias regional-locales anticentralistas, de trabajadores sindicalizados, etcétera, todo esto con el apoyo de ONGs, asociaciones de sociedad civil, medios electrónicos de comunicación, voceros-profesionales activos en el espacio público, redes internacionales.

Se crea así una suerte de microciudadanía social más que directamente política, una parte de la cual lucha por establecer sus derechos de identidad (Della Porta 2015). Surgen diversas culturas societales, como las llama Kymlicka, que "en una sociedad liberal moderna son inevitablemente pluralistas, comprendiendo a cristianos y musulmanes, judíos y ateos, heterosexuales y gays, profesionales urbanos al igual que trabajadores rurales, conservadores y socialistas. Esta diversidad es el resultado inevitable de los derechos y libertades garantizadas a una ciudadanía liberal, influyendo la libertad de conciencia, asociación, palabra, disenso político y propiedad privada, particularmente cuando se combina con una población étnicamente diversa" (Kymlicka 1997, 24).

De aquí surge también la pregunta — reiterada en el campo político-intelectual- sobre cómo en las nuevas circunstancias se puede superar ya no el atomismo de los individuos, sino que el de estas múltiples identidades para crear un sujeto popular, o de clase, o un sujeto revolucionario. Es decir, un sujeto macro-estructural, enraizado en las fuerzas sólidas de la historia, se dice, pensando idealmente en la esfera de la producción, o en el plano de la contradicción central de clase contra clase.

Al contrario, la desaparición o fragmentación del macro-sujeto por implosión, así como la disipación de los "grandes relatos" que alegan los posmodernos, podrían entenderse como una genuina expresión del predominio creciente de la sociedad civil con sus identidades colectivas y corporaciones, movimientos sociales y agrupaciones comunitarias sobre el Estado y la política tradicional. Desde el punto de vista de la democracia, se trataría de una suerte de post-democracia liberal (Innerarity 2017), transformada precisamente en este variopinto ensamblaje de grupos de interés, generaciones etarias, comunidades territoriales, manifestaciones simbólicas, procesos de integración desviada, de lucha y exclusión, de ruptura y afirmación moral. No sería ya el individuo 
monádico el agente principal, esa abstracción de una ciudadanía que se manifestaba solamente a la hora de la contabilidad de los votos, ni tampoco existiría un pueblo soberano por encima de sus divisiones de ideas e intereses, de experiencias y deseos. No hay sujeto revolucionario a la vista; en el mejor de los casos, puede haber el clivaje élites versus pueblo favorecido por el populismo, o corrientes de resentimiento o incluso de rechazo de la política convencional en beneficio de caudillos o liderazgos carismáticos.

Tal vez tampoco sea cierto, como suele decirse, que estemos frente al vaciamiento de las comunidades, ya que ahora reaparecen bajo la forma de esos numerosos grupos a veces ligados por una intensa solidaridad interna entre sus miembros, al mismo tiempo que poseen un agudo sentido de diferenciación externa respecto de los demás grupos o a algunos grupos en particular (inmigrantes, por ejemplo). Ni es verdad que haya desaparecido el potencial de una esfera pública deliberativa; sólo que en el presente ella no aparece ya bajo la noción habermasiana ${ }^{31}$ (Habermas 2015, cap. 7), ni se manifiesta a la manera ateniense, necesariamente razonante, en que suele imaginarla o suponerla la academia. Por el contrario, es una esfera de deliberación mediada y altamente jerarquizada, en la que concurren los medios tradicionales y nuevos de comunicación, las redes sociales con sus múltiples grupos identitarios, la circulación de imágenes en un permanente juego de rostros y emociones, la transmisión de micro-textos más propensos a la invectiva y el insulto que al diálogo reflexivo y el argumento razonado.

Incluso, es posible que esa esfera deliberativa ajena a la alta cultura coexista con una cultura más densamente racionalizada, sin que ésta haya desaparecido de la sociedad moderna tardía. En efecto, como nunca antes, hay disponible una abundancia de argumentos interesantes en la blogósfera y en revistas y boletines electrónicos, en seminarios y conferencias académicas, en charlas transmitidas por internet y mediante la presencia de intelectuales públicos que representan vigorosamente dispares causas y alimentan el pluralismo de la democracia liberal contemporánea. Aquél del que habla Isaiah Berlin, que enfrenta a grupos

${ }^{31}$ Un autor caracteriza esta esfera con los siguientes términos o elementos "nucleares": (1) deliberación, (2) reciprocidad, (3) autodeterminación, (4) ciudadanía, (5) el Estado, (6) soberanía, (7) racionalidad comunicable, (8) regulación, (9) formación de la voluntad soberana, (10) leyes constitucionales (Susen 2018). 
con discursos y valores inconmensurables pero que, a pesar de todo, deben aceptar la convivencia de sus propios dioses con los dioses de los otros, o bien aprender a vivir una vida sin dioses ni profetas como reclamaba Max Weber en una famosa conferencia (Weber 2004, 28).

Es hora entonces de examinar el tercer concepto nuclear de la cultura liberal, uno que es especialmente ineludible en esta discusión: el capitalismo.

\subsection{La cultura del mercado}

"Es un gran mérito de la sociedad liberal el que reduzca la necesidad de acuerdos al mínimo compatible con la diversidad de opiniones individuales que existen en una sociedad libre", arguye Hayek. Pero la democracia sólo puede sobrevivir si sus ciudadanos aceptan el hecho de que el consenso compartido siempre será limitado, y que eso significa que los propósitos para los que el gobierno puede ser usado son también mínimos. "El precio que tenemos que pagar por un sistema democrático es la restricción de la acción estatal a aquellos campos en los que el acuerdo es posible", escribió. Mientras el capitalismo hace posible la democracia, "si los ciudadanos de esa democracia caen bajo el influjo de un credo anticapitalista, eso significa que la democracia inevitablemente se destruirá a sí misma"

Jerry Z. Muller, The Mind and the Market: Capitalism in Western Thought $(2003,367)^{32}$

La tercera dimensión que interesa explorar aquí es aquella que pone en relación a la cultura liberal con el capitalismo de mercado. Desde el punto de vista de la economía política contemporánea, este vínculo resulta de suyo evidente. Pues, como señala Jessop - a quien citamos in extenso en este punto-, "el liberalismo proclama que las relaciones económicas, políticas y sociales se organizan mejor mediante elecciones formalmente libres y actores racionales que buscan avanzar en sus propios intereses materiales e ideales en un marco institucional que, por accidente o diseño, maximiza la cobertura de la libre elección”. Esto se traduce, continúa Jessop, en el hecho de que el liberalismo respalda la expansión de una economía de mercado; es decir, la mercantilización de todos los factores de producción, incluyendo la fuerza de trabajo, así como los in-

${ }^{32}$ Citas corresponden a Hayek (1997, 184-185). 
tercambios formalmente libres y monetizados del mayor número de prácticas posibles. Políticamente implicaría que las decisiones colectivas se lleven a cabo en un Estado constitucional con poderes sustantivos limitados de intervención económica y social, y comprometido con maximizar la libertad formal de los actores en la economía y el poder sustantivo de los sujetos legalmente reconocidos en la esfera pública. Estos últimos, en uso de la libre asociación, podrían emprender cualquier actividad que no se halle prohibida por la constitución o la ley. "Estos tres principios concluye Jessop - pueden entrar en conflicto en relación con la magnitud de relaciones anárquicas de mercado, procesos de decisión colectiva y autoorganización espontáneas, como también respecto de las libertades formales y sustantivas disponibles para sujetos económicos, legales y civiles" (Jessop 2002, 453).

En tanto, el vínculo del capitalismo, los mercados y las burocracias con la cultura ha sido un tema más complejo de tratar, según muestra la sociología de Max Weber. En ambos polos, del mercado y las burocracias, Weber veía en operación procesos de racionalización. En torno al primero operaba la racionalización de la economía; pues aquello que en definitiva creó el capitalismo, escribe, "fue la empresa duradera y racional, la contabilidad racional, la técnica racional, el derecho racional; a todo esto había de añadir la ideología racional, la racionalización de la vida, la ética racional en la economía" (Weber 2012, pos. 9372). En torno al segundo polo - las burocracias - se moviliza la racionalización política occidental, dado que "Occidente es el único que ha conocido el 'Estado' como organización política, con una 'constitución' racionalmente establecida, con un derecho racionalmente estatuido y una administración de funcionarios especializados guiada por reglas racionales positivas: las 'leyes'; fuera de Occidente, todo esto se ha conocido de modo rudimentario, pero siempre faltó esta esencial combinación de los elementos característicos decisivos" (Weber 2012, pos. 1168).

La pregunta que se impone entonces es cómo, en medio de estos procesos de racionalización de doble origen, se desenvuelve la racionalización de la cultura y de los mundos de vida individuales, plano en donde se expresarían las tensiones y las contradicciones de la cultura liberal, en especial en relación con los mercados.

La dificultad de la respuesta weberiana tiene que ver, en este caso, con el hecho de que el mismo Weber, según sostiene una parte de la academia dedicada a su obra, sería, "en gran parte, responsable de la 
falta de claridad que rodea sus análisis de la 'racionalidad' y la relación mutua entre procesos históricos de racionalización multifacéticos", siendo sus discusiones sobre aquellos términos "dispersas y fragmentadas", con el efecto de que a veces tienden "más a mistificar que a iluminar" (Kalberg 1980, pos. 1146).

En efecto, un conocido estudio identifica no menos de 16 diferentes sentidos en que Weber utiliza el término "racional" en una sola de sus obras, La ética protestante y el espíritu del capitalismo (Weber 2012). Ahí emplea el vocablo con significados tan variados como: ponderado (en el sentido de cuidadoso, prudente, reflexivo), sistemático, calculable, impersonal, instrumental, exacto, cuantitativo, reglado (sujeto a precepto, ordenación o regla), predecible, metódico, resuelto (con propósito, decidido), sobrio, escrupuloso, efectivo, inteligible, consistente (Brubaker 2010, 2).

Un buen número de aquellos rasgos y características formarían parte del "espíritu del capitalismo"; o sea, de la cultura puritana que según Weber dio origen al ordenamiento económico, estatal y cultural del capitalismo. Él era perfectamente consciente, además, de la dificultad que entrañaba la polisemia de los términos "racional" y "racionalización". Pero le parecía inevitable. Según manifiesta en otro pasaje, por ejemplo, "para el irreligioso, toda conducción de vida (Lebensführung) religiosa es irracional, como lo es toda conducción de vida ascética (jede asketische Lebensführung) para el hedonista, aun cuando, con el criterio de un valor supremo, sea una "racionalización"'. Y concluye afirmando: "Si este trabajo nuestro sirve para algo lo será por lo menos para descubrir el múltiple sentido del concepto, aparentemente unívoco, de lo "racional"' (Weber 2012, pos. 2176, nota 8).

De hecho, tras el aparente desorden de la polisemia weberiana de lo "racional" y lo "racionalizado", no es difícil vislumbrar un tipo característico de economía - la economía capitalista moderna - y el ordenamiento formal-legal del Estado, con su peculiar administración burocrática, metódica dedicación al trabajo de la ética protestante, la idea del deber profesional entendido como vocación, y la conducción de la propia vida del emprendedor weberiano orientada originalmente por un control ascético hacia la acción racional y racionalizadora.

Mas, ¿qué decir de la cultura asociada a los mismos fenómenos de racionalización y burocratización de base capitalista? 
En principio, ya lo vimos, la ética protestante y el espíritu del capitalismo son el principal vector de aquella cultura racionalizada, la cual encuentra su ámbito de expresión en los mercados. Desde este punto de vista, se trata pues de una cultura sin asociatividad, en el sentido de las comunidades fraternales, de solidaridad o de lazos de reciprocidad, sino que construida sobre la base de relaciones contractuales: comunidades, por tanto, puramente racionales. Como señala Weber en Economía y sociedad, a la entrada del famoso capítulo V inconcluso sobre el mercado,

frente a todas las configuraciones de tipo 'comunidad', (...) que regularmente sólo encierran una racionalización parcial de su actuar en comunidad (...) aparece ahora como tipo de todo actuar racional en comunidad la relación asociativa [Vergesellschaftung] que, en virtud del cambio, tiene su escenario en el mercado. Debe hablarse de un mercado tan pronto como concurren, aunque sólo sea de una parte, una pluralidad de interesados en el cambio y en las probabilidades de cambio. (Weber 2014, 694)

Modelo entonces de acción racional y de procesos de racionalización con impacto sobre la Lebensführung de los grupos participantes, el mercado,

en cuanto tal, es la relación práctica de vida más impersonal en la que los hombres pueden entrar. [De hecho], cuando el mercado se abandona a su propia legalidad, no repara más que en la cosa, no en la persona, no conoce ninguna obligación de fraternidad ni de piedad, ninguna de las relaciones humanas originarias portadas por las comunidades de carácter personal. Todas ellas son obstáculos para el libre desarrollo de la nuda relación comunitaria de mercado y sus intereses específicos, en cambio, éstos son las tentaciones específicas para todas ellas. Intereses racionales instrumentales determinan los fenómenos del mercado en medida especialmente alta, y la legalidad racional, en particular la inviolabilidad formal de lo prometido una vez, es la cualidad que se espera del copartícipe en el cambio, y que constituye el contenido de la ética del mercado... (Weber 2014, 695)

Buena parte de las incomodidades y malestares observados en, y con, el capitalismo contemporáneo, particularmente dentro de la cultura 
liberal de mercado, tienen su origen en dicho diagnóstico weberiano, que el propio autor resume en estas frases lapidarias: "El mercado 'libre', esto es, el que no está sujeto a normas éticas, con su explotación de la constelación de intereses y de las situaciones de monopolio y regateo, es considerado por toda ética como cosa abyecta entre hermanos" (Weber 2014, 695).

En suma, son varios los aspectos de la cultura del capitalismo de mercado que a los ojos de Weber aparecen en inevitable tensión, incluso contradicción a veces, con los valores culturales de la tradición liberal. Si sólo nos atenemos al breve capítulo $\mathrm{V}$ incompleto, pueden señalarse los siguientes aspectos:

- Primero, es una cultura esencialmente racional, centrada en el intercambio en dinero y basada en el cálculo sistemático de las posibilidades de intercambio. Paradojalmente, a este mecanismo nada de lo humano le es ajeno; procesa necesidades y deseos, satisfacciones e ilusiones. Al centrarse su operación exclusivamente en los medios, la racionalidad instrumental del mercado puede conducir a situaciones irracionales de consumo. En su interior, "todo va"; lo sagrado y lo profano quedan reducidos allí a un mismo valor de cambio.

- Segundo, es una cultura de vínculos leves, delgados, livianos; al decir de Weber, son relaciones asociativas racionales, coetáneas y sucesivas, cada una de las cuales tiene un carácter efímero, ya que se extinguen con la entrega de los bienes intercambiados. Es, por tanto, una cultura de medios y usos, de prácticas y operaciones, de funciones y computaciones. Carece de profundidad cognitiva. Da lugar, típicamente, a una cultura utilitaria de masas que se desenvuelve en una esfera no deliberativa.

- Tercero, con todo, genera una particular experiencia comunitaria. Actúa, dice Weber, "comunizando" gracias a relaciones de intereses reales de sus partícipes actuales o potenciales. Desde este punto de vista, crea la relación práctica de vida más impersonal en la que los hombres pueden entrar, orientada exclusivamente por el interés en los bienes de cambio. Diversos autores hablan por lo mismo de los egoísmos característicos del mercado, de lo gélido de los sentimientos que de él emanan, de su ética puramente competitiva, calculadora, regida por el poder de comprar y vender. El propio Weber declara: "El mercado, en plena contraposición a todas las otras relaciones comunitarias, que siempre suponen confraternización personal y, casi siempre, parentesco de sangre, es, en sus raíces, extraño a toda confraternización" (Weber 2014, 695). 
- Cuarto, el mercado amenaza a las culturas de todas las demás esferas de la sociedad, sometiéndolas a su propia lógica del intercambio (comercializándolas, mercantilizándolas). En términos semejantes a los empleados por Marx, Weber sostiene que "los vínculos sagrados estamentales y tradicionales son los obstáculos, paulatinamente eliminados, de la formación racional de los precios en el mercado; por el contrario, los monopolios condicionados en sentido puramente económico son su última consecuencia" (Weber 2014, 698). La tendencia, en el capitalismo, es poner el máximo de bienes y actividades, de cualquier tipo, en situación de mercado; o sea, sujetarlos a las posibilidades del intercambio por dinero. Esto trae consigo constantes disputas sobre la extensión tolerable de la mercabilidad; por ende, sobre lo que el dinero no puede (Sandel 2012) o sí puede comprar (Peña 2017).

-Quinto, por último, el mercado resuelve mediante la creación de contextos de intercambio problemas de coordinación en sociedades complejas, de suerte que el resultado, como señala Weber, "en el caso de pleno desarrollo de la llamada economía monetaria (...), es de tal índole como si se hubiera creado un orden para conseguirlo" (Weber 2014, 695). Algo semejante a lo que en su momento, a la salida de la Segunda Guerra Mundial, describió Polanyi (2001) y comenta Hayek, cuando se refiere a "aquello que Karl Polanyi ha descrito como la formación espontánea de un orden policéntrico; un orden que no resulta del hecho que todos los factores sean tomados en cuenta por un único centro, sino que es producido por la respuesta de los elementos individuales a sus respectivos entornos" (Hayek 2014, 160-61).

En suma, la cultura del capitalismo entra en tensión con los mercados en los cuales parcialmente se origina, revelando - ya desde el siglo XIX - su tendencia hacia una racionalización puramente formal, funcional e instrumental de la sociedad, la que se ve sometida a la lógica de los medios con abstracción de fines y valores.

En las interpretaciones más avanzadas de los mercados - de Hayek (2014) a Pellicani (1994, cap. VIII) y Fligstein y Dauter (2007), para citar cuatro ejemplos muy distintos entre sí- éstos actúan a la manera indicada por Polanyi (2001), ordenando infinitos intercambios, valorizando en función del interés propio de los participantes los costos y precios de los bienes y servicios, procesando de manera instantánea una masa inimaginablemente grande de información sobre necesidades, deseos, preferencias y oportunidades de todos los agentes por el lado de 
la demanda, el de la oferta y el de las intermediaciones, en los niveles local, provincial, nacional, regional y global. A partir de un tal macroordenamiento - que opera por medio de una suerte de inteligencia colectiva y distribuida, automáticamente, a espaldas de los participantes (una "mano invisible"33) - los mercados se hallan en condiciones de coordinar actividades altamente complejas y de producir un régimen de saber-poder inherente, el cual es típico del liberalismo y que define, en términos del mercado, la relación con el Estado. Como dice Foucault en su análisis del neoliberalismo, el homo economicus, el sujeto agente del mercado, le fija un límite al poder del soberano (el homo juridicus). Le dice: no debes intervenir en ese orden creado por el mercado. "Pero, ¿por qué se lo dice? No debes porque no puedes. Y no puedes en el sentido de que 'eres impotente'. ¿Y por qué eres impotente, o por qué no puedes? No puedes porque no sabes, y no sabes porque no puedes saber" (Foucault 2016b, 326). ${ }^{34}$

${ }^{33}$ Usado aquí como una metáfora de la metáfora empleada por A. Smith, con el propósito de indicar que esta última ha sido adoptada durante el siglo XX como una etiqueta que sirve para aludir a dos ideas importantes (y separadas), sugeridas inicialmente por Smith: primero, la del principio de las consecuencias no deseadas y, segundo, la doctrina de la emergencia espontánea de orden (Cremaschi 2017). A propósito de la historia de la metáfora smithsiana, puede consultarse Kennedy (2009; 2011).

${ }^{34}$ Foucault cita en este punto a Adam Smith, quien sostiene que, con el advenimiento de una economía de mercado, el soberano queda "liberado de una tarea que no podría tratar de cumplir - la vigilancia de todos los procesos económicos - sin exponerse infaliblemente a ser engañado de mil maneras". A continuación, comenta, en línea con el clásico argumento hayekiano, que "el carácter incognoscible de la totalidad del proceso no sólo rodea la racionalidad económica, también la funda. El homo economicus es el único oasis de racionalidad posible dentro de un proceso económico cuya naturaleza incontrolable no impugna la racionalidad del comportamiento atomístico del homo economicus; al contrario, la funda. Así, el mundo económico es opaco por naturaleza. Es imposible de totalizar por naturaleza. (...) La economía es una disciplina que comienza a poner de manifiesto no sólo la inutilidad de un punto de vista sino la imposibilidad de un punto de vista soberano, de un punto de vista del soberano sobre la totalidad del Estado que él debe gobernar". Y concluye Foucault: "El liberalismo, en su consistencia moderna, se inició precisamente cuando se formuló esa incompatibilidad esencial entre, por una parte, la multiplicidad no totalizable característica de los sujetos de interés, los sujetos económicos, y, por otra, la unidad totalizadora del soberano jurídico" (Foucault 2016b, 325-326). Sobre la relación entre el pensamiento de Foucault respecto del liberalismo y neoliberalismo y los estudios de Weber sobre racionalidad y mercados, ver Flew (2015). Asimismo, sobre la crítica foucaultiana al neoliberalismo, ver Flew (2014). 
Esta forma de operación de los mercados - como una máquina que facilita, promueve y acelera los intercambios vitales para la reproducción de la sociedad - crea una visión de lo humano en que todo se reduce a intercambios, costos y beneficios, dinero y apropiación privada. El carácter expansivo de los mercados, que ni el Estado mínimo liberal ni el Estado de bienestar han podido limitar sino sólo regular variablemente, genera a lo largo de la historia premoderna, moderna y sobre todo tardo-moderna fuertes malestares y reacciones. Así, por ejemplo, Justus Möser (1720-1794) inauguró el argumento según el cual el mercado destruye el pluralismo al golpear las bases económicas de las particularidades culturales locales (Muller 2003). Tal argumento adquiere ahora - en condiciones de globalización de la economía capitalista y de los mercados (Tomlinson 2007) - plena vigencia.

A su turno, Daniel Bell (1996), en su libro Las contradicciones culturales del capitalismo, manifiesta su preocupación, según bien resume Fawcett, por el hecho de que "las virtudes del trabajo enérgico, dedicación y responsabilidad social sobre cuya base el capitalismo liberal se había desarrollado estaban siendo sustituidas por un creciente permisivismo liberal, laxitud ética y un espíritu lúdico infantil de satisfacciones de corto plazo" (Fawcett 2104, pos. 7033). En tiempos más recientes, ya en el presente siglo, Geuss percibe un significativo descontento con aspectos teóricos, morales y políticos del liberalismo. Por largo tiempo, explica, padece de una falta de potencial inspirador; es disolvente de los modos tradicionales de vida y sus valores asociados, pero menos efectivo en reemplazarlos por algo distintivo y admirable; se acomoda confortablemente con algunos de los aspectos menos nobles de la sociedad comercial; no parece tener contribución alguna que hacer frente a la degradación del planeta, y las ideas liberales como individualismo, tolerancia, límites del poder estatal parecen o bien ser miopemente confusas o una mera máscara de un diseño hegemónico (Geuss 2002, 320-321).

Pasemos ahora al último concepto, la cultura de la modernidad, que es el horizonte frente al cual se ha desplegado esta reflexión.

\subsection{Las discordancias de la modernidad}

Por encima de todo, la modernidad es un proyecto transformador basado en un imaginario social que busca crear un nuevo tipo de sociedad: el orden político y social está basado en una visión del futuro 
en lugar del pasado, que en consecuencia se reinterpreta a la luz de las demandas del presente. En ella, existe un fuerte énfasis en la capacidad del hombre y su agencia para transformar el mundo. Esto es lo que le entrega a la condición de modernidad su base para transformaciones históricas en la constitución política y social de la sociedad en su conjunto.

Gerard Delanty, "Europe in world regional perspective" $(2015,428)$

La cuarta y última dimensión que nos interesa abordar pone en relación los factores de la cultura liberal que hasta aquí venimos explorando con las coordenadas de nuestra época, la modernidad tardía (Giddens 1990). ${ }^{35}$ En efecto, el liberalismo y la cultura liberal —asociados con la democracia y el capitalismo de mercado- se desenvuelven dentro de los confines de la modernidad, sea en su rama Ilustrada (descendiente de Kant y Mill, por ejemplo) o no (vinculada a Hobbes y Rousseau, por ejemplo). ¿Qué entendemos por modernidad para los efectos de nuestro estudio? Como señala el epígrafe de esta sección, se trata ante todo de un programa de transformación social que pone énfasis en la capacidad de la agencia humana guiada por la razón. Y, según explica el autor de la cita, tal modelo cognitivo o ideas sobre la razón pueden describirse variadamente como "libertad (tanto en el sentido de freedom como de liberty, dudosa distinción ${ }^{36}$ ), autonomía, autodeterminación individual y colectiva, igualdad" (Delanty 2015, 427-428).

Tales ideas harían posible un determinado imaginario social, una proyección de sí misma de la sociedad, una manera de vislumbrar posibilidades futuras. Enseguida, dice el autor, por su propia naturaleza,

${ }^{35}$ Ver además Beck, Giddens y Lash (1994); Bauman (2000); Archer (2012). Según Giddens, una de las características principales de la modernidad tardía es que la reflexividad se introduce en la base misma de la reproducción del sistema. Consiste en el hecho de que "las prácticas sociales son continuamente examinadas y reformadas a la luz de la información obtenida sobre esas prácticas, alterando constitutivamente su naturaleza". Así ocurre, dice, en todas las sociedades. Pues en todas las culturas las prácticas sociales son continuamente alteradas a la luz de los descubrimientos sobrevivientes. "Pero sólo en la modernidad la revisión de las tradiciones se radicaliza para ser aplicada, en principio, a todos los aspectos de la vida humana, incluyendo la intervención tecnológica en la vida material. (...) Lo que caracteriza a la modernidad no es abrazar lo nuevo por su novedad, sino la presunción de una reflexividad completa, que por cierto incluye la reflexión sobre la naturaleza de la misma reflexión" (Giddens 1990, 38-39).

${ }^{36}$ Ver a este respecto Carter (2016). 
estas ideas proporcionan una base para contestar y desafiar al poder. De este modo las sociedades modernas estarían caracterizadas por

un cuestionamiento argumentativo fundado en esas ideas, que forman el contendido estructurante de su modelo cognitivo y le proporcionan una estructura epistémica o modo de conocimiento reconocible. (...) La modernidad es por tanto más que una condición caracterizada por ideas y conocimiento; es, además, una condición societal en la cual ciertos arreglos institucionales están dispuestos para reflejar ese modelo cultural. El modelo societal, o la formación social de la modernidad, puede por eso mismo apreciarse en los términos específicos de constitución del Estado, el capitalismo y las relaciones sociales. (Delanty 2015, 428-429)

Cubrimos, entonces, territorio conocido. La modernidad, encarnada como proyecto por la sociedad burguesa del tiempo de Marx, aparece como una fuerza de transformación revolucionaria de las condiciones materiales (capitalismo), políticas (Estado formalmente democrático), sociales (lucha de clases) y culturales (liberalismo y derechos de las personas), cuyas dinámicas entrecruzadas conducen al período de mayor cambio que haya conocido la historia. Proclaman Marx y Engels en su Manifiesto:

La época de la burguesía se caracteriza y distingue de todas las demás por el constante y agitado desplazamiento de la producción, por la conmoción ininterrumpida de todas las relaciones sociales, por una inquietud y una dinámica incesantes. Las relaciones inconmovibles y mohosas del pasado, con todo su séquito de ideas y creencias viejas y venerables, se derrumban, y las nuevas envejecen antes de echar raíces. Todo lo que se creía permanente y perenne se esfuma, lo santo es profanado, y, al fin, el hombre se ve constreñido, por la fuerza de las cosas, a contemplar con mirada fría su vida y sus relaciones con los demás. (Marx y Engels 2015, pos. 275)

En términos semejantes se pronuncia Max Weber, todavía más cerca del esquema que aquí empleamos. Este autor parte por la pregunta más general, pertinente incluso para nuestra generación en la modernidad periférica. La formula así: 
Tratar de los problemas de la historia universal para un hijo del moderno mundo cultural europeo implica necesaria y legítimamente plantearlos desde la siguiente problemática: ¿qué serie de circunstancias han llevado a que precisamente en el suelo de Occidente, y sólo aquí, se hayan dado ciertas manifestaciones culturales, mismas que - al menos tal y como solemos representárnoslas- se encuentran en una dirección evolutiva de alcance y validez universales? (Weber 2012, pos. 1123)

Según Weber, la respuesta se encuentra en el momento formativo de la modernidad y del capitalismo moderno, momento cuando en el contexto europeo converge una serie de procesos, únicos en su tiempo: surgimiento de una filosofía de matices racionalistas; ciencia que hoy reconoceríamos como válida, fundada en teoría y experimentación racionales; una ciencia jurídica racional; música armónica racional; racionalización del uso de la bóveda y otros elementos arquitectónicos y, en general, racionalización de todo el arte que llevó a cabo el Renacimiento; literatura impresa destinada a la prensa y las revistas; universidades y academias dedicadas al cultivo sistematizado racionalmente de las especialidades científicas y a la formación del especialista como elemento dominante en la cultura; funcionarios especializados como piedra angular del Estado moderno y de la moderna economía europea; parlamentos con representantes del pueblo periódicamente elegidos; Estado como organización política con una constitución racionalmente establecida, con un derecho racionalmente estatuido y una administración de funcionarios especializados guiados por reglas racionales positivas.

Lo mismo ocurre "con el poder más importante de nuestra vida moderna: el capitalismo", continúa nuestro autor (Weber 2012, pos. 1168). ${ }^{37}$ En este punto, en vez de seguir la rudimentaria tesis de que el

${ }^{37} \mathrm{La}$ tesis weberiana sobre la interrelación de elementos que concurren a dar expresión a la modernidad europea suele utilizarse a veces para establecer una suerte de equilibrio virtuoso entre sociedad civil, Estado y mercados. Por ejemplo, se ha sostenido que "un aspecto definitorio de la modernidad europea, haciendo una descripción general, es que la relación entre Estado, el capitalismo y sociedad civil evolucionó de tal forma que ni el Estado ni el capitalismo predominó uno sobre otro; el poder de las élites políticas y económicas fue contenido por intereses organizados y movimientos sociales o por la sociedad civil. La relativa fuerza de la sociedad civil jugó un papel formativo en la configuración de la modernidad, pero la contienda entre el Estado y la emergente sociedad de mercado fue también relevante" (Delanty 2015, 431). 
afán de lucro y la tendencia a enriquecerse monetariamente en el mayor grado posible serían los rasgos centrales del capitalismo, Weber alega la necesidad de "abandonar de una vez para siempre un concepto tan elemental e ingenuo con el que nada tiene que ver (y mucho menos con su espíritu)" con el capitalismo, debiendo considerarse en cambio como central "la moderación racional de este irracional impulso lucrativo". Luego, el capitalismo se identifica con el trabajo incesante y racional, la ganancia siempre renovada, la rentabilidad. "Cuando se aspira de modo racional al lucro de tipo capitalista, la actividad correspondiente se basa en un cálculo de capital; es decir, se integra en una serie planificada de prestaciones útiles reales o personales", de tal suerte que al final la generación de un excedente sirva para aumentar continuamente la vida de la empresa. Luego, "lo decisivo de la actividad económica [capitalista] consiste en guiarse en todo momento por el cálculo del valor dinerario aportado y el valor dinerario obtenido..." (Weber 2012, pos. 1178-1968).

Lo más característico del capitalismo occidental, sin embargo, es "la organización racional-capitalista del trabajo formalmente libre" (Weber 2012, pos. 1231); la organización industrial racional que calcula las probabilidades del mercado y no se deja llevar por la especulación irracional o política. A esto cabe agregar la separación de la economía doméstica y la industria - entre el patrimonio industrial y los patrimonios personales - y la consiguiente contabilidad racional. Asimismo, la aparición de burgueses y proletarios en torno a la organización del trabajo libre como industria y, con ello, de la lucha de clases moderna, estructurada sobre el antagonismo entre ambos grupos. Adicionalmente, el capitalismo occidental se habría visto favorecido por los avances de la técnica y la aplicación de los conocimientos científicos, la índole racional del derecho y la administración.

Lo propiamente específico de la modernidad occidental, entonces, sería, por un lado, el influjo del racionalismo económico — esto es, de la moderna industria y los mercados racionalmente organizados- y, en sentido inverso, el influjo sobre la economía del derecho y la administración racionales y de la "capacidad y aptitud de los hombres para determinados tipos de conducción de vida (Lebensführung) práctico racional" (Weber 2012, pos. 1310). El origen de esta última disposición se encuentra en la difusión del "espíritu del capitalismo", en el sentido weberiano de un nuevo estilo de vida sujeto a ciertas normas, sometido 
a la ética protestante (Weber 2012, pos. 1873). O bien, según explica el autor en otra parte, si utilizamos la expresión "espíritu del capitalismo moderno" para designar aquella mentalidad que "aspira a obtener un lucro ejerciendo sistemáticamente una profesión, una ganancia racionalmente legítima, (...) es por la razón histórica de que dicha mentalidad ha encontrado su realización más adecuada en la moderna empresa capitalista, al mismo tiempo que ésta puede reconocer en aquélla su más adecuado impulso mental" (Weber 2012, pos. 1959).

La idea misma de que la modernidad capitalista entraña una incesante actividad, actividad incansable dice Weber (2012, pos. 2027) - es decir, que el hombre existe para el negocio y el trabajo, y no viceversa-, termina sin embargo apartándose de su base ascético-religiosa y, en adelante, se mantendrá motivada únicamente por las recompensas del éxito capitalista. Así, "al renunciar al mundo, el ascetismo cristiano (...) había logrado dominarlo desde los claustros. (...) Ahora se produce el fenómeno contrario: se lanza al mercado de la vida, cierra las puertas de los claustros y se dedica a impregnar con su método esa vida, a la que transforma en vida racional en el mundo..." (Weber 2012, pos. 3910). ${ }^{38}$ Esto ocurre "en una época en que el moderno capitalismo ha triunfado ya, emancipándose de sus antiguos asideros" (Weber 2012, pos. 2069), situación que, como vimos, lamenta Daniel Bell, quien ve en esa cesura la causa más profunda de la transformación del capitalismo en una empresa irracional y, de su cultura actual, en un mero remedo (Bell 1996) que buscaría justificar "un tipo de conducción de vida (Lebensführung), sin más finalidad aparente que el enriquecimiento" (Weber 2012, pos. 2094). Según señala gráficamente este mismo autor hacia el final de La ética protestante:

El caparazón (Gehäuse) ha quedado vacío de espíritu; quién sabe si definitivamente. En todo caso, el capitalismo victorioso no ne-

${ }^{38}$ En otro pasaje, Weber expande esta idea. "El puritano quiso ser un hombre profesional; nosotros tenemos que serlo también, pues desde el momento en que el ascetismo abandonó las celdas monásticas para instalarse en la vida profesional y dominar la eticidad intramundana, contribuyó en lo que pudo a construir el grandioso cosmos de orden económico moderno que, vinculado a las condiciones técnicas y económicas de la producción mecánico-maquinista, determina hoy con fuerza irresistible el estilo vital de cuantos individuos nacen en él (no sólo de los que en él participan activamente), y de seguro lo seguirá determinando durante muchísimo tiempo más" (Weber 2012, pos. 5488) 
cesita ya de este apoyo religioso, puesto que descansa en fundamentos mecánicos. También parece haber muerto definitivamente la rosada mentalidad de la riente sucesora del puritanismo, la "Ilustración", y la idea del "deber profesional" ronda por nuestra vida como un fantasma de ideas religiosas ya pasadas. (Weber 2012, pos. 5488)

La experiencia de una acción transformadora desprovista ya de cualquier base espiritual, o religiosa, es ahora una de las claves de comprensión de la modernidad tardía, tal como expresa Marshall Berman:

Hay una forma de experiencia vital - la experiencia del tiempo y el espacio, de uno mismo y de los demás, de las posibilidades y los peligros de la vida - que comparten hoy los hombres y mujeres de todo el mundo de hoy. Llamaré a este conjunto de experiencias la "modernidad". Ser modernos es encontrarnos en un entorno que nos promete aventuras, poder, alegría, crecimiento, transformación de nosotros y del mundo y que, al mismo tiempo, amenaza con destruir todo lo que tenemos, todo lo que sabemos, todo lo que somos. (...) Nos arroja a todos en una vorágine de perpetua desintegración y renovación, de lucha y contradicción, de ambigüedad y angustia. Ser modernos es formar parte de un universo en el que, como dijo Marx, "todo lo sólido se desvanece en el aire". (Berman 2014, pos. 250)

Esta descripción, así como las reflexiones de Weber sobre la acción transformadora permanente que tiene lugar en la modernidad recuerdan al Fausto de Goethe, para quien también "en el principio era la Acción". ${ }^{39}$ Como es bien sabido, el mismo Berman encarna en la figura del Fausto su análisis de la modernidad capitalista, otorgándole al per-

${ }^{39}$ El párrafo completo es éste: “Dice aquí: ¿En el principio estaba la Palabra’? / ¡Ya me atasco! ¿Me ayuda a seguir alguien? / ¡No puedo darle tanto valor a la ‘Palabra'! / Tengo que traducirlo de otro modo, / si el Espíritu me ilumina bien. / Dirá aquí: 'En el principio existía el Sentido\%. Piensa bien esta línea, la primera; / que tu pluma no vaya apresurada. / El Sentido, ¿es quien todo lo hace y obra? / Debía ser: 'En el principio estaba / la Fuerza'. Pero ya, cuando lo escribo, / algo me avisa que no he de dejarlo. / ¡Me socorre el Espíritu! De pronto lo he entendido: / y pongo: 'En el principio existía la Acción"” (Goethe 2005, 37-38). En otra parte se lee, de boca de un personaje distinto: "Dieweil ich bin, muss ich auch tätig sein", es decir: "Dado que existo, debo ser activo" (Goethe 2005, 203, traducción revisada por el autor). 
sonaje goetheano el papel creativo-destructivo propio de un empresario schumpeteriano. Y más: lo convierte en una figura que por la intermediación de Mefistófeles consigue para sí todos los poderes intramundanos ( $\sin$ ir acompañados por ninguno de los ascetismos weberianos): conocimiento, dinero, sexo, fama, fueros reales, artilugios, invulnerabilidad, estatus más allá de la ley y la justicia, hasta alcanzar el mayor poder, el del emprendedor (capitalista) que se apropia y transforma por completo su entorno, haciendo así retirarse el mar para convertir las tierras conquistadas en un gran puerto industrial abierto al comercio mundial. La acción transformadora del Fausto no se detiene ante ningún obstáculo; ni siquiera ante la vida de los viejos Baucis y Filemón, pareja a cargo de la pequeña iglesia del lugar, con su campana tradicional y su tilo, vestigios de un mundo que debe desaparecer arrasado por la modernidad. Señala Berman: "El único modo de que el hombre moderno se transforme, como descubrirá Fausto y también nosotros, es transformando radicalmente la totalidad del mundo físico, social y moral en que vive" (Berman 2014, pos. 756).

Detengámonos todavía un momento más en el campo de las contradicciones culturales más profundas que la sociología descubre en el encuentro entre modernidad, capitalismo avanzado y cultura liberal.

El ya citado sociólogo liberal Ralf Dahrendorf ha planteado provocativamente la siguiente tesis: la modernidad misma, al "liberar a la gente de restricciones y abrirle oportunidades de elección”, debió pagar "un precio en previsibilidad y orden" (Dahrendorf 1994, 60-61). Una fuerza liberadora se habría transformado en una fuerza de incertidumbre y anomia. ¿Cómo pudo ocurrir esto? Porque, en su incontenible avance por superar constricciones normativas y extender la libertad de elegir al mayor número posible de personas y asuntos, la modernidad "afecta también a esos vínculos más sólidos que trascienden a los cambios sociales a corto plazo y anclan a la gente en la más profunda corriente de la cultura" (Dahrendorf 1994, 63); esto es, en aquellos arreglos institucionales a los cuales las personas pertenecen, más que por elección, por fuerzas que se hallan fuera de su alcance, como la familia, ciertas comunidades, la sociedad, el sexo, determinadas localidades, tal vez grupos generacionales, de vocación y clase social (Dahrendorf 1994, 63). En algún punto, concluye Dahrendorf, hay un umbral más allá del cual el coste de la modernidad comienza a exceder sus benefi- 
cios. Es el punto donde desaparecen Baucis y Filemón o la sustentabilidad del planeta comienza a ser amenazada.

Este argumento, posteriormente reiterado bajo diferentes formas por la sociología del siglo XX, aunque con desigual valoración, sostiene pues que la libre elección individual, una vez que escapa al marco de los mercados y de la democracia para penetrar todos los ámbitos de la cultura, opera fragmentando a las comunidades, acentuando los procesos de individuación, invadiendo aquellos ámbitos previamente excluidos de la libre opción y transformando progresivamente todas las relaciones en contratos, en opciones, en posibilidades de intercambio.

De pronto todo parece ser válido ("todo va”). En el horizonte aparece la figura del free for all. Estamos, dice Dahrendorf, en camino hacia la anomia; aquel estado social en el cual las normas reguladoras de la conducta han perdido validez y por ende se vive en una situación de extrema incertidumbre, "en la cual nadie sabe qué comportamiento esperar de los demás" (Dahrendorf 1994, 40). Incluso, abriga la sospecha —igual como le ocurre a Merton $(1964,166)$ - de que en las sociedades modernas puede existir una tendencia hacia la anomia (Dahrendorf 1994, 43). Al deslizarse hacia la anomia, la modernidad tardía nos devolvería a un estado de naturaleza hobbesiano, en el que la vida del hombre se vuelve "solitaria, pobre, ingrata, cruel y breve", según la famosa frase, y reinan la inseguridad y el miedo, la desconfianza y el descontento.

Cerremos esta parte con una breve mención a la perspectiva que adopta la sociología posmoderna sobre los fenómenos de la cultura liberal. Según afirma Bauman:

en tiempos de modernidad líquida, la cultura (...) se organiza para acomodarse a la libertad individual de elección y a la responsabilidad individual por esa elección; su función es asegurar que la elección debe ser — y seguirá siendo siempre — una necesidad e inevitable deber de la vida, mientras la responsabilidad por la elección y sus consecuencias permanece donde ha sido puesta por la moderna condición humana líquida. Es decir, sobre los hombros del individuo, ahora en su condición de manager encargado de la política "de la [propia] vida y su único ejecutivo". (Bauman $2011,12)^{40}$

${ }^{40}$ Para una visión menos esquemática sobre Bauman, pueden consultarse los estudios contenidos en Jacobsen y Poder (2008). 
Sugiere el autor que la reducción de la cultura a una suerte de apéndice de la libre elección individual se produciría por las mismas fuerzas que favorecen liberar los mercados de cualquier limitación extra económica: social, política o ética. Se buscaría, en consecuencia, nada más que motivar el consumo de los infinitos bienes culturales disponibles, en el camino (ahora de regreso desde la anomia) que cada sujeto recorre para auto-crearse administrando su propia identidad. En vez de Ilustración, o ennoblecimiento de la cultura, ahora sólo cabría esperar la continua creación de nuevas necesidades y deseos, de manera de evitar que las personas alcancen un estado de satisfacción. ${ }^{41}$

Estos fenómenos de autogerencia personal, emprendimiento del self y toda la ideología de autoayuda que se formula como un refuerzo del (neo)liberalismo en el plano personal e íntimo aparecen justificados así en estas líneas de Ulrich Beck:

La proporción de oportunidades de vida que se halla esencialmente clausurada para los procesos de decisión individual está decreciendo y la proporción de la biografía que se halla abierta y debe ser construida biográficamente aumenta continuamente. (Beck 1992, 135)

Este fenómeno, a su vez, sería provocado por la subjetivación e individuación de los riesgos y contradicciones producidos por las instituciones y la sociedad del capitalismo tardío.

En breve, según plantea Beck, hemos llegado al punto en que los individuos están forzados a buscar "soluciones biográficas" para "contradicciones sistémicas". Expresado en el vocabulario de otras aproximaciones sociológicas, los sujetos estarían siendo forzados a gestionar gerencialmente respecto de sí mismos la disyunción producida entre integración social (mundos de vida) e integración sistémica (en la esfera

${ }^{41}$ También éste, se recordará, es un motivo fáustico. En efecto, la apuesta de Fausto con Mefistófeles consiste precisamente en saber si éste puede llevar a aquél a un estado de plenitud, momento en que estaría dispuesto a entregar su alma. Fausto: "Si a un instante le digo alguna vez: / ¡Detente, eres tan bello!, / puedes atarme entonces con cadenas; / y acepto hundirme entonces de buen grado; / pueden doblar entonces la campana, / y libre quedarás de mi servicio: / ¡párese allí el reloj con sus agujas! / ¡puede acabar el tiempo para mí!” (Goethe 2005, 50). La modernidad, en cambio, es trabajo incansable, continuo esfuerzo de producción y consumo, fuga hacia delante, deseo inacabable de saber y transformar el mundo. 
de la economía y los mercados). En un reciente libro (Kennedy 2017, 171), se encuentran varios ejemplos que ilustran este punto. Por ejemplo, dentro de las sociedades avanzadas se demanda e insiste que cada ciudadano ejerza su derecho absoluto a vivir su propia vida regido por una ética de autorrealización (Beck y Beck-Gernsheim 2002, 22-29). La autorrealización se transforma, pues, en un deber y obliga a la autoorganización y autotematización de la biografía personal. Giddens, por su lado, agrega que la autorrealización dentro de un ámbito personal estrechamente interconectado y construido en torno a elecciones de estilos de vida deviene un recurso clave para la planificación de la vida y de las actividades diarias (1990, cap. 4; 1991, 6).

En suma, la modernidad tardía ofrece el contexto histórico-epocal más general dentro del cual se desenvuelven los procesos contemporáneos de cultura liberal, liberalismo, democracia representativa y su crisis, variedades de capitalismo con sus diferentes juegos de Estado/ mercado a nivel de naciones y regiones del mundo y en el curso de diversas trayectorias de modernidad. Sin embargo, el núcleo central de significados de la modernidad occidental mantiene su arquitectura conceptual en un amplio espectro de situaciones. En todos los casos se hace presente a través de una creciente confianza en la razón y la acción transformadora de agentes humanos dotados de derechos, autonomía y capacidad de elección; $y$, por ende, generando un progresivo aumento de reflexividad de las sociedades, conjuntamente con la aplicación del conocimiento científico y técnico a la producción y la administración, en la gestión burocrática del Estado y las empresas y la conformación de democracias liberal-constitucionales. ${ }^{42}$

Desde el punto de vista de los procesos de base de la modernidad occidental y de sus consecuencias culturales, probablemente el análisis

${ }^{42}$ No abordaremos aquí las múltiples modernidades que surgen en condiciones socio-históricas, político-institucionales y culturales distintas, ya sea dentro, pero especialmente fuera, del espacio occidental (Eisenstadt 2000; 2002; Mota y Delanty 2015). A este propósito, Delanty (2015, pos. 433-436) identifica seis trayectorias básicas hacia la modernidad: la europea, del Nuevo Mundo, poscolonial, islámica, reactivas y alternativas. De modo que el mundo multipolar y postoccidental daría paso a una diversidad de modelos culturales cuyo desarrollo más o menos diferenciado dependería, en gran medida, según este autor, de la forma como el predominio mundial del capitalismo y de los mercados sea integrado por cada trayectoria y de la manera que en cada caso se adopte la democracia, punto de vista que comparto. 
más vigente continúa siendo aquel propuesto por Max Weber hace un siglo, con su tesis de la racionalización de todos los aspectos y esferas de valor (u órdenes de vida) de la sociedad. Efectivamente, en todos ellos, sus lógicas diferenciadas y autónomas quedan interferidas por procesos de racionalización funcional; producto del avance combinado de la burocratización de cualquier tipo de organizaciones y de la mercantilización generalizada y global, con la consecuencia de que los individuos y las sociedades - y sus libertades para autodeterminarsequedan atrapados en una "jaula de hierro". Esta imagen, creada imaginativamente por T. Parsons en su traducción de Weber, se convirtió con el tiempo en el símbolo también de su sociología:43 la "jaula" donde iría a dar el destino de la humanidad. Expresa el dominio que el poder y el dinero ejercen sobre los "mundos de vida" individuales, aquellas prácticas y relaciones que conforman la existencia cotidiana de las personas y se despliegan en la comunicación y en las formas culturales intersubjetivamente compartidas. Esas prácticas y relaciones son "colonizadas" por los mecanismos sistémicos del poder y el dinero, la burocratización y los mercados, siendo redefinidas en términos de racionalidad instrumental e integración sistémica (Habermas 2010, 205-206, 837-853; Alexander 1988). El núcleo mismo de la experiencia liberal y su cultura - la autonomía individual y la libertad de elegir en el plano de los valores mediante la deliberación pública - se ven así amenazados por procesos de racionalización instrumental que penetran los "mundos de vida" y sustituyen o subordinan su propia racionalidad comunicativa, forzando a los sujetos - como vimos antes - a volverse administradores y empresarios de sí mismos.

Culmina así con Weber un diagnóstico de época que la literatura suele calificar como culturalmente pesimista (Seidman 1983; Kaesler 2017). Efectivamente, su problemática principal gira en torno a la cuestión de la autonomía y libertad individuales en medio de sociedades crecientemente racionalizadas (Kim 2017), y sus conclusiones anuncian un mundo que se halla preso de una lógica de racionalización unilateral,

${ }^{43}$ Weber escribe de un Stahlhartes Gehause (casa de duro acero o caparazón duro como el acero), que T. Parsons tradujo del alemán al inglés como "iron cage", “jaula de hierro". Véanse mayores antecedentes en Weber (2012 pos. 5488, pos. 7655). Para un análisis más detallado del hallazgo y empleo de esta metáfora, ver Baehr (2001). 
cuando no irracional, en cuanto a sus orientaciones finales; envuelto en procesos de cientifización, tecnificación e intelectualización de las sociedades que provocan su desencantamiento y la pérdida de toda ilusión; junto con el dominio fáustico-emprendedor y transformador de la naturaleza y el entorno institucional y humano que conduce eventualmente a la construcción autoimpuesta de una "jaula de hierro".

\section{CONCLUSIÓN: LIBERALISMO EN TIEMPOS TURBULENTOS}

El análisis realizado lleva a concluir que la cultura liberal se encuentra sujeta contemporáneamente a un doble movimiento.

Por un lado, se encuentra sujeta a los ajustes internos de su núcleo conceptual básico, como sea que éste se defina en cuanto a su composición y los elementos que lo integran. Por ejemplo, podrá constatarse que las ideas de autonomía y libre elección adquieren preeminencia por encima de razón y responsabilidad. O bien, que se otorga mayor peso a los fenómenos de la individuación y a las relaciones contractuales que a los vínculos comunitarios y las ligazones más profundas con la cultura. O bien que la esfera privada - que el liberalismo buscaba preservar frente al poder público - termina siendo "colonizada" por el mercado y la administración, creándose nuevos tipos de desequilibrio entre propietarios y ciudadanos o entre intimidad y democracia.

Del mismo modo, pueden observarse ajustes entre las diferentes tradiciones a los que aquellos conceptos se adscriben. Puede ser, por ejemplo, que ciertas ideas relativas a la libertad orientada por una racionalidad de valores únicos, absolutos o dominantes, sean desplazadas por ideas de libertad compatibles con el pluralismo de valores (Berlin 2014). O bien, puede ocurrir que, en diferentes momentos o lugares, el liberalismo sea entendido esencialmente como libertad negativa o libertades positivas, como libertad individual o libertad social, como la libertad del liberalismo clásico o la del nuevo liberalismo inglés de mediados del siglo XX, más cercano a nociones de Estado y políticas de bienestar, según vimos (Gaus et al. 2018).

Por otro lado, la cultura liberal se encuentra sujeta al dinamismo producido por las variables relaciones de su núcleo conceptual y de éste con algunas categorías afines en el campo semántico que se encuentran también sometidas a proceso de evolución y cambio; en concreto, exa- 
minamos aquí al liberalismo en su relación con el Estado administrador, la democracia liberal, el capitalismo de mercado y la modernidad tardía como expresión de época. Nuestro análisis muestra que, en cada una de estas dimensiones, la cultura liberal se encuentra sujeta a una serie de tensiones y contradicciones, producto de las cambiantes relaciones entre los elementos internos de la ideología liberal y su interacción con los factores de su inmediato entorno externo.

Por ejemplo, desde esta perspectiva puede constatarse que un liberalismo que valoraba altamente la libertad negativa da paso, con posterioridad a la Segunda Guerra Mundial, a una ciudadanía de derechos sociales, inspirada más en T. H. Marshall y en la política pública de Beveridge y su escuela que en los pensadores clásicos del liberalismo. Puesto en otros términos, el liberalismo individual del egoísmo posesivo (Macpherson 2011) es asumido y transformado por ideas socialdemócratas propias del siglo XX (Esping-Andersen 1985; Berman 2006).

Asimismo, la democracia liberal —en sus variadas formas - parece estar siendo enfrentada, y a veces sometida, por democracias administradas, autoritarias, plebiscitarias, de partido único, de caudillos, de controles disciplinarios, etcétera, siendo empujada en esa dirección por factores políticos, económicos, tecnológicos, militares y culturales (Levitsky y Way 2002; 2010; Csillag y Szelényi 2015). Lo mismo ocurre con el vínculo entre cultura liberal y capitalismo de mercado, vínculo que se ha tornado de alto riesgo en el seno de la democracia representativa, dando lugar a un creciente sometimiento de la política al dinero y de los representantes del demos a los poderes fácticos. La misma modernidad tardía se ve amenazada por incesantes procesos de racionalización weberiana que llevan, por un lado, a la negación de los ideales emancipatorios de la razón ilustrada y, por el otro, a una colonización de la esfera pública, y de la razón pública por los intereses privados predominantes en la economía y la sociedad.

A su turno, las relaciones entre estos varios componentes se modifican y dan lugar a diversas combinaciones, como aparece ahora con creciente claridad cuando se estudian las nuevas configuraciones gerenciales del Estado y su gobernanza (Pollitt y Bouckaert 2011); los tipos de democracias y de organización de la política (Habermas 2015; Caramani 2017); las variedades de capitalismo (Hall y Soskice 2001; Hall 2015) y las modernidades múltiples a las que nos referimos más arriba. 
Por todas partes, el orden liberal parece estar siendo superado y muestra fisuras, tensiones, contradicciones y quiebres. Una ola de descontento y malestares recorre a Occidente (Luce 2017), manifestándose en la prensa ilustrada (Streeck 2014; Rodrik, 2017) y en el mundo académico (Lilley 2011; Deneen 2018). De hecho, las críticas al liberalismo abundan, así como a la cultura que ha contribuido a formar durante los últimos dos siglos. Freeden, por ejemplo, a quien citamos a continuación in extenso, señala:

Hay quienes condenan el liberalismo como una doctrina pretenciosa, riesgosa y enervante bajo cuyas banderas se ha provocado daño social e individual. Numerosos postestructuralistas han acusado a los liberales de fomentar falsas ideas de armonía y cooperación, y de ser obcecadamente individualistas. Algunos de sus oponentes culturales lo culpan por ponerse por encima de la sabiduría tradicional acumulada. Ha sido denunciado como un manifiesto en favor del capitalismo, incluso si es compasivo. Ha sido repudiado como un haz de ideas occidentales que busca reemplazar o subyugar otras interpretaciones culturales significativas de la vida social, ofreciendo cobertura no sólo para la explotación a gran escala dentro de Europa, sino que, además, para las políticas coloniales europeas. Ha sido criticado como una doctrina que fracasó en proporcionar a las mujeres su debido lugar social; repudiado como una visión exagerada de la racionalidad humana a expensas de la emoción y las pasiones, o desacreditado como la teoría complaciente de un acuerdo artificial que pasa por alto las enriquecedoras diversidades y discontinuidades entre los seres humanos. (Freeden 2015, 8)

Efectivamente, no resulta difícil observar, después de todo lo que llevamos dicho, que varios de los aspectos centrales del liberalismo - como idea, ideología y cultura, propios de su núcleo o asociados a él- se encuentran en una encrucijada, sujetos a tensiones o forzados a subsistir contradictoriamente. A modo de resumen, ofrecemos la siguiente tabla sinóptica que en una columna reúne una serie de elementos y rasgos de la doctrina liberal —adoptados de Freeden (2015, 12) y Geuss (2002) — y en la columna del frente se los cualifica por sus tensiones y contradicciones que hemos visto a lo largo de estas páginas o que agregamos aquí. 
TABLA SINÓPTICA DE LAS TENSIONES DEL LIBERALISMO

Elementos y rasgos de la doctrina
1. El liberalismo es una doctrina de
base universal o universalizable, en la
medida en que se funda en la libertad
y la autonomía de la razón
2. Teoría del poder limitado para pro-
teger los derechos individuales y ase-
gurar el espacio en que las personas
pueden vivir sin opresión guberna-
mental.

3. Teoria de interacciones y mercados libres que favorecen el intercambio mutuo de bienes.
Tensiones y contradicciones

1. Es un fenómeno históricamente limitado al mundo occidental, cuyo vocabulario político ha llegado a dominar, pero cuya difusión ha sido dispareja y corre por cuenta de elementos asociados como el capitalismo y la democracia (en ocasiones de contenidos iliberales).

2. Poder expansivo del Estado administrativo; tecnologías intrusivas de supervisión y control; racionalización de la esfera privada y disciplinamiento práctico.

3. Mercantilización y comodificación de la sociedad y mundos de vida de las personas; deriva de libertades individuales hacia libertad de consumo.

4. Crisis de los "grandes relatos" del progreso; aguda estratificación de las oportunidades de desarrollo personal y de grupos sociales por condiciones de desigualdad estructural y su reproducción sistémica.

5. Límites fiscales (y crisis) del Estado de bienestar; crítica neoliberal de las políticas sociales; cuestionamiento de los liberalismos sociales y colonización privada de la esfera pública.

6. Tensiones propias de la explosión de diversidades, políticas de identidad, cierre de fronteras, neonacionalismos y anomia.

7. Sociedad civil está siendo transformada por expansión de mercados, contractualismo, vaciamiento de comunidades y difusión de formas burocráticas de autoridad. 
8. Teoria liberal se halla comprometida con el individualismo. Sociedad goza de un buen orden sólo en la medida en que los individuos están seguros en sus propiedades y personas.

9. Liberalismo expresa las tendencias de la modernidad y la época presente, al fundar la acción transformadora de los sujetos en el conocimiento y la libre iniciativa de innovación y crítica en todas las esferas de la vida.
8. Excesos del individualismo egoísta, ruptura de vínculos de solidaridad, fragmentación de la sociedad, competencia desatada de todos contra todos. Multiplicación de las vulnerabilidades sociales de los individuos aislados.

9. El "pacto fáustico" del progreso liberal capitalista ha desembocado en la destrucción de la naturaleza y deja tras de sí -en su lógica de creación destructiva- una huella de escombros. $^{44}$

En un mismo tren crítico, otro estudioso del liberalismo propone agrupar en seis categorías los principales ítems que generarían una recurrente ansiedad respecto a la durabilidad, e incluso deseabilidad, del liberalismo: incoherencia programática, anacronismo ético, insustentabilidad política, subidentificación inspiracional, inadecuación medioambiental e idealismo hipócrita. Concluye este autor que, en su conjunto, estos seis reclamos podrían servir como una suerte de "minimanual diagnóstico de la ansiedad liberal para uso de autoevaluación" (Fawcett 2014, pos. 70337049). O bien, como lapidariamente dijo en su momento Eric Hobsbawm, reputado historiador británico, "ninguno de los problemas mayores de la humanidad en el siglo XXI puede resolverse por medio de los principios que todavía dominan en los países desarrollados de Occidente: crecimiento económico y progreso técnico ilimitados, ideal de la autonomía individual, libertad de elección y democracia electoral". 45

${ }^{44}$ Pensamos aquí la clásica cita a Walter Benjamin: "Hay un cuadro de Klee que se llama 'Angelus Novus'. En él se representa a un ángel que parece como si estuviese a punto de alejarse de algo que lo tiene pasmado. Sus ojos están desmesuradamente abiertos, la boca abierta y extendidas las alas. Y éste deberá ser el aspecto del ángel de la historia. Ha vuelto el rostro hacia el pasado. Donde a nosotros se nos manifiesta una cadena de datos, él ve una catástrofe única que amontona incansablemente ruina sobre ruina, arrojándolas a sus pies. Bien quisiera él detenerse, despertar a los muertos y recomponer lo despedazado. Pero desde el paraíso sopla un huracán que se ha enredado en sus alas y que es tan fuerte que el ángel ya no puede cerrarlas. Este huracán lo empuja irrefrenablemente hacia el futuro, al cual da la espalda, mientras que los montones de ruinas crecen ante él hasta el cielo. Ese huracán es lo que nosotros llamamos progreso" (Benjamin 1989, 183).

${ }^{45}$ En la revista Prospect, marzo 2007, citado en Fawcett (2014, pos. 7.016). 
Qué duda cabe: las perspectivas del liberalismo no son promisorias. El núcleo conceptual de la doctrina, así como sus conceptos adyacentes y periféricos, lo mismo que el entorno de significados más relevantes de la cultura liberal se hallan bajo una enorme presión histórica. Tras dos siglos de un desarrollo que pareció ascendente, ininterrumpido, glorioso incluso, al punto de poder decirse que tras las derrotas del fascismo y el comunismo (los socialismos reales) la historia del pensamiento político había llegado a su fin, ${ }^{46}$ ahora, sin embargo, al comenzar el siglo XXI, dicho pensamiento parece agotado o anacrónico. Max Weber se adelantó un siglo a esta percepción. Con razón ha podido decirse de él que era un "liberal pesimista" o un "liberal desesperado" (Mommsen 1974, 95). O bien, como manifiesta otro autor: "Era un liberal dedicado, aunque era también pesimista de su futuro" (Eliaeson 1998, 47).

Bien puede ser que ésta sea la única manera de ser liberal en el siglo XXI, así como Weber había aprendido de Goethe:

[La] renuncia a la universalidad fáustica de lo humano es una condición del obrar valioso en el mundo actual, y que, por tanto, la "acción" y la "renuncia" se condicionan recíprocamente de modo inexorable (...). Con esto expresaba Goethe su despedida, su renuncia a un periodo de humanidad integral y bella que ya no volverá a darse en la historia, del mismo modo que no ha vuelto a darse otra época de florecimiento ateniense. (Weber 2012, pos. 5470-5488)

${ }^{46}$ Lo que se escribió, exactamente, fue: "Lo que podríamos estar atestiguando no es sólo el fin de la Guerra Fría, o el paso de algún periodo particular de la posguerra, pero sí el fin de la historia como tal; esto es, el punto final de la evolución ideológica de la humanidad y la universalización de la democracia liberal de Occidente como el modelo último de gobierno humano" (Fukuyama 1989). Con todo, hay que anotar que desde temprano el optimismo (o espejismo) de Fukuyama encontró decididos contradictores. Por ejemplo, a mediados de los años 1990, Derrida escribe: "Porque debe ser señalado con fuerza, en tiempos en que algunos tienen la audacia de neo-evangelizar en nombre de los ideales de la democracia liberal, que se ha erigido a sí misma como el ideal de la historia humana: nunca la violencia, la hambruna, la exclusión y la opresión económica han afectado a tantos seres humanos en la historia de la Tierra y de la humanidad. En vez de cantar el advenimiento del ideal de democracia liberal y del mercado capitalista en la euforia del fin de la historia, en vez de celebrar el 'fin de las ideologías' y el fin de los grandes relatos emancipatorios, nunca dejemos de considerar este evidente y macroscópico hecho, compuesto de innumerables paisajes singulares de sufrimiento: no existe grado de progreso que nos permita ignorar que nunca antes, en números absolutos, tantos hombres, mujeres y niños han sido subyugados, privados o exterminados en la Tierra" (Derrida 1994, 106). 


\section{REFERENCIAS}

Abbey, R. 2005. "Is Liberalism Now an Essentially Contested Concept?" New Political Science 27 (4): 461-80.

Alexander, G. 2005. "There Are No Alternatives to the 'Western' Model of Democracy”. Brown Journal of World Affairs 12 (1): 155-163.

Alexander, J. 1988. "Ensayo de revisión: la nueva teoría crítica de Habermas: su promesa y problemas". Sociológica 3 (7-8).

Ambriz Arévalo, G. 2016. "El concepto de sobredeterminación en Althusser. Aportes para la distinción de dos etapas en la teoría de Marx". Agora. Papeles de Filosofía 35 (2): 177-197.

Anderson, P. 2000. "Renewals". New Left Review 1 (13): 1-20.

Aninat, I. \& S. Razmilic. 2018. Un Estado para la ciudadanía. Estudios para su modernización. Santiago: Centro de Estudios Públicos.

Archer, M. S. 2012. The Reflexive Imperative in Late Modernity. Cambridge: Cambridge University Press.

Arneson, R. J. 2016. "Locke and the Liberal Tradition". En Companion to Locke, editado por M. Stuart, 528-545. Blackwell Publishing Ltd.

Baehr, P. 2001. "The 'Iron Cage' and the 'Shell as Hard as Steel': Parsons, Weber, and the Stahlhartes Gehäuse. Metaphor in the Protestant Ethic and the Spirit of Capitalism". History and Theory 40: 153-169. doi:10.1111/0018-2656.00160.

Bauman, Z. 2000. Liquid Modernity. Cambridge: Polity Press.

. 2011. Culture in a Liquid Modern World. Londres: Polity.

Beck, U. 1992. Risk Society. Londres: Sage.

Beck, U., A. Giddens \& S. Lash. 1994. Reflexive Modernization: Politics, Tradition, and Aesthetics in the Modern Social Order. California: Stanford University Press.

Beck, U. \& E. Beck-Gernsheim. 2002. Individualization. Londres: Sage.

Beckert, J. 2007. "The Great Transformation of Embeddedness: Karl Polanyi and the New Economic Sociology". MPIfG Discussion Paper 07 (1).

Beetham, D. 1989. "Max Weber and the Liberal Political Tradition". European Journal of Sociology 30 (02): 311-323.

Bell, Daniel. 1996. The Cultural Contradiction of Capitalism. 20th Anniversary Edition. New York: Basic Books.

Bell, Duncan. 2014. "What is Liberalism?” Political Theory 42 (6): 628-715.

Bello Hutt, D. 2017. "Revisión judicial y democracia deliberativa en términos de teoría departamental y constitucionalismo popular". Bajo Palabra 17: 191212. https://doi.org/10.15366/bp2017.17.009.

Benjamin, W. 1989. "Tesis de filosofía de la historia”. En Discursos Interrumpidos I, 175-191. Madrid: Taurus.

Bensaid, D. 2011. "Volver a la cuestión judía. Introducción”. En Karl Marx: Sobre la cuestión judía. Barcelona: Editorial Gedisa (edición digital). 
Berlin, I. 2014. Freedom and Its Betrayal: Six Enemies of Human Liberty. Princeton, NJ: Princeton University Press (edición digital).

Berman, M. 2014. Todo lo sólido se desvanece en el aire. La experiencia de la modernidad. México D.F.: Grupo Editor Siglo Veintiuno (edición digital).

Berman, S. 2006. The Primacy of Politics: Social Democracy and the Making of Europe's Twentieth Century. Cambridge: Cambridge University Press.

Bernstein, R. 2003. "Rorty's Inspirational Liberalism". En Richard Rorty, editado por C. Guignon \& D. R. Hiley, 124-138. Cambridge: Cambridge University Press (edición digital).

Beveridge, W. 1945. Why am I a Liberal? Londres: Herbert Jenkins.

Boas, T. C. \& J. Gans-Morse. 2009. "Neoliberalism: From New Liberal Philosophy to Anti-Liberal Slogan". Studies in Comparative International Development 44 (2): 137-161.

Bogaards, M. 2009. "How to Classify Hybrid Regimes? Defective Democracy and Electoral Authoritarianism". Democratization 16 (2): 399-423.

Brown, J. 2017. "Democratizing Accounting: Reflections on the Politics of 'Old' and 'New' Pluralisms". Critical Perspectives on Accounting 43: 20-46. https:// doi.org/10.1016/j.cpa.2016.11.001/.

Brown, W. 2015. Undoing the Demos: Neoliberalism's Stealth Revolution. New York: Zone Books.

Brubaker, R. 2006. The Limits of Rationality. An Essay on the Social and Moral Thought of Max Weber. Londres y Nueva York: Rutledge.

Brunner, J. J. 1998. "Malestar en la sociedad chilena: ¿de qué, exactamente, estamos hablando?” Estudios Públicos 72: 173-198. https://www.cepchile.cl/ cep/site/artic/20160303/asocfile/20160303183735/rev72_brunner.pdf/.

Cain, O. 2016. "The Ideal of Freedom in Modern Times and Beyond. On Liberalism and Neoliberalism". University of California, Berkeley. http://livecritical-theory.pantheon.berkeley.edu/wp-content/uploads/2016/06/Clain_TheIdeal-of-Freedom-in-Modern-Times-and-Beyond.pdf.

Campbell, J. L. 2002. "Ideas, Politics, and Public Policy". Annual Review of Sociology 28 (1): 21-38.

Campbell, J. L. \& O. Pedersen. 2015. "Policy Ideas, Knowledge Regimes and Comparative Political Economy”. Socio-Economic Review 13 (4): 679-701.

Caramani, D. 2017. "Will vs. Reason: The Populist and Technocratic Forms of Political Representation and Their Critique to Party Government". American Political Science Review 111 (1): 54-67. doi.org/10.1017/S0003055416000538.

Carter, I. 2016. "Positive and Negative Liberty". En The Stanford Encyclopedia of Philosophy, editado por Edward N. Zalta. https://plato.stanford.edu/archives/ fall2016/entries/liberty-positive-negative/.

Castells, M. 2007. "Communication, Power and Counter-power in the Network Society”. International Journal of Communication 1: 238-266.

Chmielewski, A. J. 2007. "The Enlightenment's Concept of the Individual and its Contemporary Criticism". Polish Journal of Philosophy 1 (2): 41-59. 
Coggan, P. 2013. The Last Vote: The Threats to Western Democracy. Londres: Allen Lane.

Collier, D., F. D. Hidalgo \& A. O. Maciuceanu. 2006. "Essentially Contested Concepts: Debates and Applications". J. Polit. Ideol. 11: 211-246. doi: $10.1080 / 13569310600923782$.

Cremaschi, S. 2017. “Adam Smith's Irony and the Invisible Hand”. Iberian Journal of the History of Economic Thought 4 (1): 43-62.

Crouch, C. 2017. Post-Democracy. Cambridge UK: Polity Press.

Csillag, T. \& I. Szelényi. 2015. "Drifting from Liberal Democracy: Traditionalist/ Neo-conservative Ideology of Managed Illiberal Democratic Capitalism in Post-communist Europe". Intersections. EEJSP 1(1): 18-48.

Dahrendorf, R. 1994. Ley y orden. Madrid: Editorial Civitas.

David-Fox, M. 2006. "Multiple Modernities vs. Neo-Traditionalism: On Recent Debates in Russian and Soviet History". Jahrbücher für Geschichte Osteuropas 55: (4): 535-555.

Davis, M. C. 2017. "Strengthening Constitutionalism in Asia”. Journal of Democracy 28 (4): 147-161.

Deneen, P. J. 2018. Why Liberalism Failed. New Haven y Londres: Yale University Press (edición digital).

Delanty, G. 2015. "Europe in World Regional Perspective: Formations of Modernity and Major Historical Transformations". The British Journal of Sociology 66 (3): 420-440.

Della Porta, D. 2015. "Democratic Practices in Anti-Austerity Movements: From Forum to Camps, from Latin America to Europe". En Social Protests and Democratic Responsiveness: Assessing Realities in Latin America and the Caribbean and the European Union 13-34. Hamburgo: EU-LAC Foundation. https://eulacfoundation.org/en/system/files/Social_Protests_eng. pdf\#page $=13 /$.

Derrida, J. 1994. Specters of Marx: State of the Debt, the Work of Mourning and the New International. Nueva York y Londres: Routledge.

Dewey, J. 1935. "The Future of Liberalism”. The Journal of Philosophy 32 (9): 225-230.

Dryzek, J. S. 2016. "Can There Be a Human Right to an Essentially Contested Concept? The Case of Democracy". The Journal of Politics 78 (2): 357-367.

Dunn, J. 1991. Western Political Theory in the Face of the Future. Cambridge: Cambridge University Press.

- 2013. Breaking Democracy's Spell. New Haven, CT: Yale University Press.

Eliaeson, S. 1998. "Max Weber and Plebiscitary Democracy". En Max Weber, Democracy and Modernization, editado por R. Schroeder, 47-60. New York: Palgrave - St. Martins Press.

Eisenstadt, S. N. 2000. "Multiple Modernities”. Daedalus 129 (1): 1-29.

Eisenstadt, S. N., ed. 2002. Multiple Modernities. New Brunswick, NJ: Transaction Books. 
Esping-Andersen, G. 1985. Politics against Markets: The Social Democratic Road to Power. Princeton: Princeton University Press.

Fawcett, E. 2014. Liberalism. The Life of an Idea. Princeton y Oxford: Princeton University Press (edición digital).

Flew, T. 2015. "Foucault, Weber, neoliberalism and the politics of governmentality". Theory, Culture and Society 32 (7-8): 317-326.

_. 2014. "Six theories of neoliberalism". Thesis Eleven 122 (1) :49-71.

Fligstein, N. \& L. Dauter. 2007. “The Sociology of Markets”. Annu. Rev. Sociol 33: 6.1-6.24.

Foucault, M. 2016a. Seguridad, territorio, población. Curso en el College de France (1977-1978). Edición establecida por M. Senellart, bajo la dirección de F. Ewald \& A. Fontana. Traducción de H. Pons. México D.F.: Fondo de Cultura Económica.

- 2016b. Nacimiento de la biopolítica. Curso en el College de France (1978-1979). Edición establecida por M. Senellart, bajo la dirección de F. Ewald \& A. Fontana. Traducción de H. Pons. México D.F.: Fondo de Cultura Económica.

Freeden, M. 1996. Ideologies and Political Theory: A Conceptual Approach. Oxford: Clarendon Press.

- 2005. Liberal Languages. Princeton: PUP.

2006. "Ideology and Political Theory". Journal of Political Ideologies 11 (1): 3-22.

- 2007. The Meaning of Ideology: Cross-disciplinary Perspectives. Oxford: Oxford University Press.

- 2013. "The Morphological Analysis of Ideology". En The Oxford Handbook of Political Ideologies, editado por Freeden, Sargent \& Stears, 115-136.

- 2015. Liberalism. A Very Short Introduction. Oxford: Oxford University Press (edición digital).

- 2017. "Crisis? How Is That a Crisis!?" Contributions to the History of Concepts 12 (2): 12-28.

- 2018. "Loose talk costs ... nothing". Journal of Political Ideologies 23 (1): 1-9.

Freeden, M. \& M. Stears. 2013. "Liberalism”. En The Oxford Handbook of Political Ideologies, editado por Freeden, Sargent \& Stears, 329-48.

Freeden, M., L. T. Sargent \& M. Stears, ed. 2013. The Oxford Handbook of Political Ideologies. Oxford: Oxford University Press.

Friedland, R. 2013. "Divine Institution: Max Weber's Value Spheres and Institutional Theory". En Religion and Organization Theory. Research in the Sociology of Organizations, editado por P. Tracey, N. Phillips \& M. Lounsbury. Bingley: Emerald.

Fuchs, C. 2014. "Social Media and the Public Sphere". Triple C 12 (1): 57-101.

Fuchs, C. \& D. Trottier. 2015. "Towards a Theoretical Model of Social Media Surveillance in Contemporary Society". Communications: The European 
Journal of Communication Research 40 (1): 113-135. doi:10.1515/commun -2014-0029.

Fukuyama, F. 1989. "The end of History?” The National Interest, summer: 3-18.

Galli, C. 2013. El malestar de la democracia. México D.F.: Fondo de Cultura Económica.

Gallie, W. B. 1956. "Essentially Contested Concepts". Proc. Aristotelian Soc. 56: 167-198. doi:10.1093/aristotelian/56.1.167.

Garver, E. 1990. "Essentially Contested Concepts: The Ethics and Tactics of Argument". Philos. Rhetoric 23: 251-270. http://www.jstor.org/stable/40237644/.

Gaus, G. 2003. Contemporary Theories of Liberalism. Londres: Sage Publications.

Gaus, G., S. D. Courtland \& D. Schmidtz. 2018. "Liberalism". En The Stanford Encyclopedia of Philosophy, editado por Edward N. Zalta. Por publicarse. https://plato.stanford.edu/archives/spr2018/entries/liberalism/.

Geertz, C. 1973. The Interpretation of Cultures. Selected Essays. Nueva York: Basic Books, Inc.

Geuss, R. 2002. "Liberalism and Its Discontents". Political Theory 30: 320-338.

Giddens, A. 1990. The Consequences of Modernity. Cambridge: Polity Press. 1991. Modernity and Self-Identity. Cambridge: Polity Press.

Giesinger, J. 2016. "Bildung im Liberalen Staat - Von Humboldt zu Rawls". En Das Pädaogische und das Politische, editado por R. Casale, H. C. Koller \& N. Ricken. 27-40. Paderborn: Schöningh. http://www.erziehungsphilosophie.ch/ publikationen/Giesinger_Bildung-Humboldt-Rawls_OA.pdf/.

Goethe, J. W. 2005. Fausto. Traducción de J. M. Valverde. Barcelona: Editorial Planeta.

Gunn, A. 2017. "Policy Entrepreneurs and Policy Formulation". En Handbook of Policy Formulation, M. Howlett \& I. Mukherjee. 265-283. Cheltenham: Edward Elgar Publishing.

Habermas, J. 2010. Teoría de la acción comunicativa. Tomo I y tomo II. Traducción de M. Jiménez Redondo. Madrid: Editorial Trotta.

2015. Between Facts and Norms. Contributions to a Discourse Theory of Law and Democracy. Traducción William Rehg. Cambridge, MA: The MIT Press.

Halikiopoulou, D., S. Mock \& S. Vasilopoulou. 2013. "The Civic Zeitgeist: Nationalism and Liberal Values in the European Radical Right". Nations and Nationalism 19 (1): 107-127.

Hall, P. A. 1993. "Policy Paradigms, Social Learning and the State". Comp. Polit. 23: 275-96.

. 2015. "Varieties of Capitalism". En Emerging Trends in the Social and Behavioral Sciences: An Interdisciplinary, Searchable, and Linkable Resource, editado por R. Scott \& S. Kosslyn. New York: John Wiley \& Sons, Inc. https:// pdfs.semanticscholar.org/9901/ad80fb2faa5121425c0c006780ed7349c990.pdf/.

Hall, P. A. \& D. Soskice. 2001. Varieties of Capitalism: The Institutional Foundations of Comparative Advantage. Oxford: Oxford University Press. 
Harper, K. 2018. "Illiberal Democracy". First Things (marzo). https://www. firstthings.com/article/2018/03/illiberal-democracy/.

Hayek, F. A. 1997. Freedom and the Economic System. Socialism and War: The Collected Works of F. A. Hayek, vol. 10, editado por B. Caldwell. Chicago: University of Chicago Press.

2014. The Market and Other Orders. The Collected Works of F. A. Hayek, vol. 15, editado por B. Caldwell. Londres y Nueva York: Routledge.

Hearn, J. 2011. "The Strength of Weak Legitimacy: A Cultural Analysis of Legitimacy in Capitalist, Liberal, Democratic Nation-States". Journal of Political Power 4 (2): 199-216. doi: 10.1080/2158379X.2011.589179.

Hegel, G. W. F. 1991. Elements of the Philosophy of Right. Edición de A. Wood y traducción H. B. Nisbett. Cambridge: Cambridge University Press.

Hibbard, S. 2015. "Religion, Nationalism, and the Politics of Secularism". En The Oxford Handbook of Religion, Conflict, and Peacebuilding, editado por A. Omer, R. S. Appleby \& D. Little. 100-123. Oxford: Oxford University Press.

Hobson, C. 2016. "Democracy: Trap, Tragedy or Crisis?". Political Studies Review 16 (1): 38-45.

Hodgson, G. M. 2017. "Karl Polanyi on Economy and Society: A Critical Analysis of Core Concepts". Review of Social Economy 75 (1): 1-25.

Horlacher, R. 2014. "¿Qué es Bildung? El eterno atractivo de un concepto difuso en la teoría de la educación alemana. Pensamiento educativo". Revista de Investigación Educacional Latinoamericana 1 (51): 35-45.

Iazzetta, O. \& M. R. Stabili. 2016. Las transformaciones de la democracia. Miradas cruzadas entre Europa y América Latina. Buenos Aires: Prometeo.

Innerarity, D. 2017. "Democracy without Politics: Why Democracy Can Seriously Harm Democracy". Studies in Media and Communication 5 (2): 76-84.

Ishay, M. 2004. "What Are Human Rights? Six Historical Controversies". Journal of Human Rights 3 (3): 359-371. doi: 10.1080/147548304200022489.

Jacobsen, M. H. \& P. Poder, ed. 2008. The Sociology of Zygmunt Bauman. Challenges and Critique. Aldershot Burlington: Ashgate Publishing Limited.

Jessop. B. 2002. "Liberalism, Neoliberalism, and Urban Governance". Antipode 3 (34): 452-472. http://www.sociologia.unimib.it/DATA/Insegnamenti/2_1931/ materiale/jessop\%202002\%20-\%20reading\%20for\%20group\%202.pdf/.

Johnston, S. 2015. American Dionysia: Violence, Tragedy, and Democratic Politics. New York: Cambridge University Press.

Kaesler, D. 2017. "Universal Rationalization: Max Weber's Great Narrative”. Irish Journal of Sociology 25 (3): 315-323.

Kahn, V. 2012. "Political Theology and Liberal Culture: Strauss, Schmitt, Spinoza and Arendt". En Political Theology and Early Modernity, editado por G. Hammill \& J. R. Lupton. 476-905. Chicago y Londres: The University of Chicago Press.

Kalberg, S. 1980. "Los tipos de racionalidad de Max Weber: piedras angulares para el análisis de los procesos de racionalización en la historia". En Max 
Weber und die Dynamik der gesellschaftlichen Rationalisierung, editado por C. Seyfarth \& W. M. Sprondel. Traducción de B. Juárez, revisada por P. Aronson y E. Weisz. Stuttgart: Enke. https://ecaths1.s3.amazonaws.com/ maxweber/7170501.3\%20-\%20Kalberg,\%20traducci\%C3\%B3n\%20BJ,\%20 Revisi\%C3\%B3n\%20EW2.docx/.

Kennedy, G. 2009. “Adam Smith and the Invisible Hand, from Metaphor to Myth”. Econ Journal Watch 6 (2): 239-63.

. 2011. "Adam Smith and the Role of the Metaphor of an Invisible Hand". Economic Affairs 31 (1): 53-57.

Kennedy, P. 2017. Vampire Capitalism: Fractured Societies and Alternative Futures. Londres: Palgrave Macmillan.

Kim, S. H. 2017. "Max Weber". The Stanford Encyclopedia of Philosophy, editado por Edward N. Zalta. https://plato.stanford.edu/archives/win2017/entries/ weber/.

Kurlantzick, J. 2013. Democracy in Retreat: The Revolt of the Middle Class and the Worldwide Decline of Representative Government. New Haven, CT: Yale University Press.

- 2016. State Capitalism - How the Return of Statism is Transforming the World. Oxford: Oxford University Press.

Kymlicka, W. 1997. States, Nations and Cultures. Assen: Van Gorcum \& Comp.

Lechner, N. 1988. Los patios interiores de la democracia. Santiago: Flacso.

1998. "Nuestros miedos. Conferencia pronunciada con motivo de la Asamblea General de Flacso en la Ciudad de México, 14 de mayo de 1998". Perfiles Latinoamericanos 13: 179-198.

- 2003. Las sombras del mañana. La dimensión subjetiva de la política. Santiago de Chile: Lom Ediciones.

Levitsky, S. \& L. A. Way. 2002. "The Rise of Competitive Authoritarianism". Journal of Democracy 13: 51-65.

. 2010. Competitive Authoritarianism: Hybrid Regimes after the Cold War. Cambridge: Cambridge University Press.

Lilla, M. 2017. The Once and Future Liberal. After Identity Politics. Nueva York: Harper Collins Publishers (edición digital).

Lilley, S., ed. 2011. Capital and its Discontents: Conversations with Radical Thinkers in a Time of Tumult. Oakland: PM Press.

Lipsky, M. 2010. Street-level Democracy: Dilemmas of the Individual in Public Services. Nueva York: The Russell Sage Foundation.

Losurdo, D. 2011. Liberalism: A Counter-History. Londres: Verso.

Löwy, M. 2004. "Le concept d'affinité élective chez Max Weber". Archives de sciences sociales des religions 127 (3): 1-6.

Luce, E. 2017. The Retreat of Western Liberalism. Nueva York: Atlantic Monthly Press.

Macpherson, C. B. 2011. The Political Theory of Possessive Individualism. Hobbes to Locke. Oxford: Oxford University Press. 
Mair, P. 2013. Ruling the Void: The Hollowing of Western Democracy. Londres: Verso.

Marx, K. 2011. Sobre la cuestión judía. Barcelona: Gedisa (edición digital).

Marx, K. \& F. Engels. 2015. El manifiesto communista. e-artnow.org (edición digital).

Maynard, J. L. \& M. Mildenberger. 2016. "Convergence and Divergence in The Study of Ideology: A Critical Review". British Journal of Political Science 10: 1-27. doi: 10.1017/S0007123415000654.

McKinnon, A. M. 2010. "Elective Affinities of the Protestant Ethic: Weber and the Chemistry of Capitalism”. Sociological Theory 28 (1): 108-126.

Merton, R. K. 1964. Teoría y estructura sociales. México D.F.: Fondo de Cultura Económica.

Mill, J. S. 1831. The Collected Works of John Stuart Mill, Volume XXII - Newspaper Writings. December 1822 - July 1831. Part I. Editado por A. P. Robson y J. M. Robson. Introducción de A. P. Robson y J. M. Robson. Toronto: University of Toronto Press; London: Routledge and Kegan Paul, 1986). http://oll.libertyfund.org/titles/256/.

- 1854. The Collected Works of John Stuart Mill, Volume XVIII. Essays on Politics and Society. Part I. Reform of the Civil Service. Editado por John M. Robson. Introducción por Alexander Brady (Toronto: University of Toronto Press; Londres: Routledge and Kegan Paul, 1977). http://oll.libertyfund.org/ titles/233/.

Minc, A. 1995. La borrachera democrática. El nuevo poder de la opinión pública. Madrid: Ediciones Temas de Hoy.

Moffitt, B. 2017. "Liberal Illiberalism? The Reshaping of the Contemporary Populist Radical Right in Northern Europe". Politics and Governance 5 (4): 112-122.

Mommsen, J. W. 1974. The Age of Bureaucracy. Oxford: Basil Blackwell, 1974.

Mota, M. \& G. Delanty. 2015. "Eisenstadt, Brazil and the Multiple Modernities Framework: Revisions and Reconsiderations". Journal of Classical Sociology 15 (2): 39-57.

Muller, J. Z. 2003. The Mind and the Market: Capitalism in Western Thought. New York: First Anchor Books Edition (edición digital).

Müller, H. P. 2017. "Der Kapitalismus und seine Lebensführung”. En Kapitalismus als Lebensform? Wirtschaft + Gesellschaft, editado por P. Sachweh \& S. Münnich. 27-45. Wiesbaden: Springer VS.

Nagel, T. 2003. "Rawls and Liberalism". En The Cambridge Companion to Rawls, editado por S. Freeman. Cambridge: Cambridge University Press.

Norval, A. 2013. "Poststructural Conceptions of Ideology". En The Oxford Hand-book of Political Ideologies, editado por M. Freeden, Sargent \& Stears. 155-174.

Nybom, T. 2007. "A Rule-Governed Community of Scholars: The Humboldt Vision in the History of the European University". En University Dynamics and 
European Integration, editado por P. Maassen \& J. P. Olsen, 55-79. Dordrecht: Springer.

OECD, Revenue Statistics" - "OECD Countries: Comparative Tables" - "Total Tax Revenue as Percentage of GDP", 2016, http://stats.oecd.org/Index. aspx?QueryId=21699.

Paz, O. 1979. El ogro filantrópico. México D.F.: Joaquín Mortiz.

Pellicani, L. 1994. The Genesis of Capitalism and the Origins of Modernity. Nueva York: Telos Press.

Peña, C. 2017. Lo que el dinero sí puede comprar. Santiago: Taurus.

PNUD. 1998. Desarrollo humano en Chile - 1998. Las paradojas de la modernización. Santiago: PNUD.

Polanyi, K. 2001. The Great Transformation. The Political and Economic Origins of Our Time. Forward by Joseph E. Stiglitz, Introduction by Fred Block. Boston: Beacon Press.

Pollitt, C. \& G. Bouckaert. 2011. Public Management Reform: A Comparative Analysis; New Public Management, Governance, and the NeoWeberian State. New York: Oxford University Press.

Rawls, J. 1996. Political Liberalism. Nueva York: Columbia University Press.

Reisman, D. 2005. Democracy and Exchange: Schumpeter, Galbraith, T. H. Marshall, Titmuss and Adam Smith. Cheltenham: Edward Elgar Publishing.

Rico, R. 2010. The Place of Religion in the Liberal Philosophy of Constant, Tocqueville and Lord Acton. Auburn: Ludwig von Mises Institute.

Rodrik, D. 2017. "Rescuing Economics from Neoliberalism". Boston Review, 6 de noviembre. http://bostonreview.net/class-inequality/dani-rodrik-rescuingeconomics-neoliberalism/.

Rosanvallon, P. 2007. "L'universalisme démocratique: histoire et problems". Texte paru dans laviedesidees.fr: 1-17. http://www.laviedesidees.fr/IMG/ pdf/20080128_rosanvallon.pdf/.

Rosanvallon, R. 2008. Counter-Democracy. Politics in an Age of Distrust. Cambridge: Cambridge University Press.

Roth, A. E. 2007. "Repugnance as a Constraint on Markets". Journal of Economic Perspectives 21 (3): 37-58.

Runciman, D. 2013. The Confidence Trap: A History of Democracy in Crisis from World War I to the Present. Princeton, NJ: Princeton University Press.

Ryan, A. 2012. The Making of Modern Liberalism. Princeton \& Oxford: Princeton University Press (edición digital).

Sandel, M. 2012. What Money Can't Buy: The Moral Limits of Markets. Penguin.

Schmidt, V. A. 2015. "Discursive Institutionalism: Understanding Policy in Context". En Handbook of Critical Policy Studies, editado por F. Fischer, D. Torgerson, A. Durnová \& M. Orsini, 171-189. Cheltenham: Edward Elgar Publishing.

- 2016. "The Roots of Neo-Liberal Resilience: Explaining Continuity and Change in Background Ideas in Europe's Political Economy". The British Journal of Politics and International Relations 18 (2): 318-334. 
Schmitter, P. 2010. "Democracy and Distrust: A Discussion of Counter-Democracy: Politics in an Age of Distrust". Perspectives on Politics 8 (3): 887-889.

Scott, A. 2012. "Capitalism as Culture and Statecraft: Weber-Simmel-Hirschman”. Journal of Classical Sociology 13 (1): 30-46.

Seidman, S. 1983. "Modernity, Meaning, and Cultural Pessimism in Max Weber". Sociological Analysis 44: 267-78.

Simmons, B. A., F. Dobbin \& G. Garrett. 2006. "The International Diffusion of Liberalism”. International Organization 60 (4): 781-810.

Skidmore, D. 2005. “Fukuyama's Dream, Huntington's Nightmare and a Grassroots Reverie". En Dar al Islam. The Mediterranean, the World System and the Wider Europe, vol. 2: The Chain of Peripheries and the new Wider Europe, editado por P. Herrmann \& A. Tausch, 165-178. Nueva York: Nova Science Publishers, Inc.

Snyder, J. 2016. "Alternative Modernities and the Late Development Trap". Presentación en la conferencia "Future Scenarios for Russia and the West", en The Harriman Institute, Columbia University, 11 de noviembre. http:// harriman.columbia.edu/files/harriman/Snyder\%20ALTERNATIVE\%20 MODERNITIES\%20Harriman.pdf/.

- 2017. "The Modernization Trap". Journal of Democracy 28: 77-91.

Stråth, B. 2013. "Ideology and Conceptual History". En The Oxford Handbook of Political Ideologies, editado por Freeden, Sargent \& Stears. 3-19.

Strauss, L. 1968. Liberalism Ancient and Modern. Chicago: University of Chicago Press.

Streeck, W. 2014. "How Will Capitalism End?”. New Left Review 87: 35-64.

Susen, S. 2018. "Jürgen Habermas: Between Democratic Deliberation and Deliberative Democracy". En The Routledge Handbook of Language and Politics, editado por R. Wodak \& B. Forchtner, 43-66. London: Routledge.

Swyngedouw, E. 2005. "Governance Innovation and the Citizen: the Janus Face of Governance-beyond-the-state”. Urban Studies 42 (11): 1991-2006.

Tanzi, V. 2011. Government versus Markets: The Changing Economic Role of the State. Cambridge: Cambridge University Press.

_. 2013. "Tax reform in Latin America: A Long Term Assessment". Paper presentado en el XXV Regional Seminar on Fiscal Policy, ECLAC, Santiago, 5 y 6 de marzo. https://www.cepal.org/ofilac/noticias/paginas/9/49309/Tanzi. $\mathrm{pdf} /$.

Thompson, J. B. 2000. Political Scandal: Power and Visibility in the Media Age. Cambridge: Polity Press.

Tomlinson, J. 2007. "Cultural Globalization". En The Blackwell Companion to Globalization, editado por G. Ritzer. 352-366. Malden, MA: Blackwell.

Triadafilopoulos, T. 2011. "Illiberal Means to Liberal Ends? Understanding Recent Immigrant Integration Policies in Europe". Journal of Ethnic and Migration Studies 37 (6): 861-880. 
Villar, C. G. 2000. “Justicia y política en la España democrática (Una reflexión a propósito de los llamados 'jueces estrella' y la judicialización de la política)”. Revista de Derecho Político 47: 27-52.

Wagner, P. 2011. "The Democratic Crisis of Capitalism: Reflections on Political and Economic Modernity in Europe". LEQS Paper 44, London School of Economics. http://www.lse.ac.uk/europeanInstitute/LEQS\%20Discussion\%20 Paper\%20Series/LEQSPaper44.pdf/.

Walzer, M. 1984. "Liberalism and the Art of Separation". Political Theory 12 (3): 315-330.

Weber, M. 1969. "Religious Rejections of the World and their Directions". En From Max Weber: Essays in Sociology, editado por H. Gerth \& C. Wright Mills. 323-359. Nueva York: Oxford University Press.

- 2004. The Vocation Lectures. Editado por D. Owen \& T. B. Strong, traducido por R. Livingstone. Indianapolis/Cambridge: Hackett Publishing.

- 2012. La ética protestante y el espiritu del capitalismo. Introducción y edición crítica de F. Gil Villegas. México D.F.: Fondo de Cultura Económica (edición digital).

. 2014. Economía y sociedad. Nueva edición, revisada, comentada y anotada por F. Gil Villegas. México D.F.: Fondo de Cultura Económica (edición digital).

Whiteside, N. 2014. "The Beveridge Report and its Implementation: A Revolutionary Project?”Histoire@Politique 24: 24-37. https://www.cairn.info/ revue-histoire-politique-2014-3-page-24.htm/.

Zachhuber, J. 2017. "Martin Luther and Modernity, Capitalism, and Liberalism". En Oxford Research Encyclopedias, 1-18. https://www.academia.edu/ 28803646/Luther_and_Modernity_Capitalism_and_Liberalism/.

Zakaria, F. 2003. The Future of Freedom: Illiberal Democracy at Home and Abroad. Nueva York: W.W. Norton \& Co.

Žižek, S. 2008. "Tolerance as an Ideological Category”. Critical Inquiry 34 (summer). EP 